ARTICLE

https://doi.org/10.1038/s41467-019-11566-2

\title{
Photo-editable macromolecular information
}

\author{
Niklas Felix König (1) ${ }^{1}$, Abdelaziz Al Ouahabi ${ }^{1}$, Laurence Oswald ${ }^{1}$, Roza Szweda (D) ${ }^{1}$, Laurence Charles (D) ${ }^{2} \&$ \\ Jean-François Lutz (iD ${ }^{1}$
}

Light-induced alteration of macromolecular information plays a central role in biology and is known to influence health, aging and Darwinian evolution. Here, we report that light can also trigger sequence variations in abiotic information-containing polymers. Sequence-coded poly (phosphodiester)s were synthesized using four phosphoramidite monomers containing either photo-sensitive or photo-inert substituents. These monomers allow different sequence manipulations. For instance, using two light-cleavable monomers containing o-nitrobenzyl ether and o-nitroveratryl ether motifs, photo-erasable digital polymers were prepared. These polymers can be decoded by tandem mass spectrometry but become unreadable after UVA exposure. The opposite behavior, i.e. photo-revealable sequences, was obtained with polymers made of two isobaric monomers containing light-cleavable o-nitrobenzyl ether and light-inert $p$-nitrobenzyl ether substituents. Furthermore, when the latter two monomers were used in conjunction with a third monomer bearing a light-inert $\mathrm{OH}$ group, site-directed photomutations were induced in synthetic polymers. This was used herein to change the meaning of binary sequences.

\footnotetext{
${ }^{1}$ Université de Strasbourg, CNRS, Institut Charles Sadron UPR22, 23 rue du Loess, 67034 Strasbourg Cedex 2, France. ${ }^{2}$ Aix Marseille Université, CNRS, UMR 7273, Institute of Radical Chemistry, 13397 Marseille Cedex 20, France. Correspondence and requests for materials should be addressed to

J.-F.L. (email: jflutz@unistra.fr)
} 
nformation-containing macromolecules are molecularly uniform polymers, in which a defined sequence of monomers is used to store a message: for example, a genetic or a digital sequence $^{1-3}$. In recent years, it was shown that intentional information can be stored in biological $^{4}$ and abiological polymers $^{5-11}$. Such polymers are promising for applications in anti-counterfeiting, traceability, cryptography, and data storage technologies ${ }^{2}$. However, until now, only the synthesis (i.e. the writing method) and the sequencing (i.e. the reading method) of these polymers have been extensively studied. There are currently very few reports that describe the reorganization (e.g. erasing, changing, revealing, or rewriting) of information sequences ${ }^{6,12,13}$. For biological polymers such as nucleic acids, sequence rearrangement is not easy to achieve using a simple physical trigger and may require epigenetics modifications or the use of a bacterial machinery ${ }^{12,13}$. For synthetic polymers on the other hand, structural design can be adjusted to enable control over information sequences; e.g. using dynamic chemical bonds or stimuliresponsive functional groups ${ }^{14-16}$. For example, our group has reported that controlled thermal degradation can be used to erase information-containing polymers ${ }^{6}$. In this earlier study, mainchain thermolabile bonds were employed, thus leading to complete polymer destruction upon mild heating. Yet, temperature is not a practical trigger for all applications, in particular for devices that operate at room temperature. A possible alternative is the use of light as a stimulus. Photo-irradiation has been widely studied in academia and industry to control the synthesis ${ }^{17,18}$, folding 19,20 , self-assembly ${ }^{21,22}$, and physico-chemical properties $^{23-25}$ of synthetic polymers. Here, we describe that light is a useful and versatile stimulus to control information sequences in digital polymers. The synthesis and characterization of digitally encoded polymers containing photo-controllable side-chains is presented herein. These polymers are constructed using four custom-made monomers containing either light-sensitive or light-inert substituents. This small monomer library enables various possibilities of sequence transformation such as erasing, mutation, and revealing.

\section{Results}

Molecular design of the light-sensitive digital polymers. Figure 1 depicts the different concepts that were studied in the present work. Sequence-coded poly(phosphodiester)s were selected as model polymers ${ }^{26}$, even though the concepts described in this article could be potentially applied to various other types of information-containing macromolecules ${ }^{3}$. Abiotic poly(phosphodiester)s are prepared by automated solid-phase chemistry using phosphoramidite protocols that have been originally introduced for chemical nucleic acid synthesis ${ }^{27,28}$. It has been already described in previous works that long digital poly(phosphodiester)s can be synthesized by this approach ${ }^{29,30}$ and decoded by mass spectrometry 31 . In order to control information sequences by light, four phosphoramidite monomers $\mathbf{M}_{\mathbf{1}}-\mathbf{M}_{\mathbf{4}}$ were synthesized and characterized in this work (Fig. 1a). Monomers $\mathbf{M}_{\mathbf{1}}$ and $\mathbf{M}_{\mathbf{2}}$ contain light-cleavable $\boldsymbol{o}$-nitrobenzyl and $o$-nitroveratryl ether motifs, respectively ${ }^{32}$. Monomer M3 contains a light inert $p$-nitrobenzyl ether substituent. Monomer M4 contains a triisopropylsilyl (TIPS)-protected $\mathrm{OH}$ group. All monomers were derived in five steps from glycerol and characterized by high-resolution mass spectrometry (HRMS) as well as ${ }^{1} \mathrm{H},{ }^{13} \mathrm{C}$, and ${ }^{31} \mathrm{P}$ NMR (nuclear magnetic resonance) spectroscopy (Supplementary Methods). To illustrate the versatility of this monomer library, different sequence transformations were investigated in this work (Fig. 1b-d). In the first strategy (Fig. 1b), photo-irradiation is used to erase information stored inside a synthetic polymer. To do so, the polymer is encoded using monomers $\mathbf{M}_{\mathbf{1}}$ and $\mathbf{M}_{\mathbf{2}}$ as a binary language. These two monomers have a different molar mass and it is therefore possible to write a digital sequence that can be decoded by tandem mass spectrometry (MS/MS) ${ }^{2}$. However, under light exposure, both $o$ nitrobenzyl and $o$-nitroveratryl side-chain moieties are cleaved, thus leading to a non-coded homopolymer. This concept permits to erase molecularly stored information without destroying the polymer main chain. In the second strategy (Fig. 1c), light is used as a trigger to reveal a hidden message stored in a polymer. Isobaric monomers $\mathbf{M}_{\mathbf{1}}$ and $\mathbf{M}_{\mathbf{3}}$ are used as bits 0 and 1 in this approach. Since these two monomers have the same molar mass, the formed sequence-coded polymer cannot be decrypted by MS/ MS. However, under light exposure, the $o$-nitrobenzyl side-chains of bit- 0 are cleaved, while the $p$-nitrobenzyl ether motifs remain unchanged. As a consequence, bit- 0 and bit- 1 have a different molar mass and their sequence can hence be revealed by MS/MS. The third approach (Fig. 1d) is inspired by irradiation-mediated mutagenesis and enables site-directed mutations in synthetic polymers. In this strategy, the polymers were synthesized using monomers $\mathbf{M}_{1}, \mathbf{M}_{3}$, and $\mathbf{M}_{\mathbf{4}}$. After synthesis, the TIPS groups of $\mathbf{M}_{\mathbf{4}}$ are cleaved, thus leading to a digital polymer, in which $\mathrm{OH}$ side groups are 0 -bits and isobaric monomers $\mathbf{M}_{\mathbf{1}}$ and $\mathbf{M}_{\mathbf{3}}$ are 1 -bits. When exposed to light, a $1 \rightarrow 0$ mutation occurs exclusively on $o$-nitrobenzyl 1-bits. As a consequence, the meaning of the information sequence can be manipulated by light.

Photo-erasable digital polymers. The photo-erasing concept was examined with a series of oligomers (Supplementary Table 1). Although long coded polymers can be prepared by phosphoramidite chemistry ${ }^{29}$, short models containing eight coded residues were studied herein for the sake of demonstration clarity. Since monomers M1 and M2 were never tested in solid-phase phosphoramidite chemistry, two homopolymers $\mathbf{H} \mathbf{1}$ and $\mathbf{H} \mathbf{2}$ were first synthesized and characterized by high-performance liquid chromatography (HPLC) (Supplementary Fig. 1), ${ }^{1} \mathrm{H}$ NMR spectroscopy (Supplementary Figs. 2 and 3), electrospray ionization-HRMS (ESI-HRMS) (Supplementary Figs. 4-7), and ${ }^{31} \mathrm{P}$ NMR spectroscopy (Supplementary Fig. 8). All these measurements evidenced formation of uniform oligomers, thus indicating that monomers $\mathbf{M} 1$ and $\mathbf{M} 2$ can be used in stepwise phosphoramidite protocols. These two homopolymers were also subjected to photo-irradiation $(\lambda=365 \mathrm{~nm})$ in order to verify that $o$-nitrobenzyl and $o$-nitroveratryl units can be quantitatively cleaved from a poly(phosphodiester) backbone. The resulting photo-modified polymers $\mathbf{H 1}^{\prime}$ and $\mathbf{H 2} \mathbf{2}^{\prime}$ were analyzed by ESIHRMS (Supplementary Figs. 4-7), which suggests full removal of the photo-cleavable side groups. Signals corresponding to partly deprotected oligomers could not be detected in these mass spectra. The formation of intermolecular thymine dimers, which generally occurs in the far- $\mathrm{UV}^{33}$, was also not detected. Digitally encoded copolymers P1-P5, in which monomers M1 and M2 were respectively used as 0-bit and 1-bit, were afterwards synthesized. Their molecular uniformity was confirmed by HPLC (Supplementary Fig. 1), ${ }^{31} \mathrm{P}$ NMR (Supplementary Fig. 9), and ${ }^{1} \mathrm{H}$ NMR (Supplementary Figs. 10-14). Figure 2 shows ESI-HRMS and MS/MS characterization of copolymer P1 containing the digital sequence 01000101 . Before irradiation, P1 was found as a major species in MS (Fig. 2a) and could be sequenced by MS/MS to recover digital information (Fig. 2c, Supplementary Table 4), applying the same dissociation rules as previously reported for poly(phosphodiester)s ${ }^{31}$ since the presence of the side groups did not induce any significant modification of the backbone fragmentation pattern. Yet, after irradiation at $\lambda=365 \mathrm{~nm}$, the formation of a fully deprotected homopolymer $\mathbf{P} \mathbf{1}^{\prime}$ was evidenced by ESI-HRMS (Fig. 2b, Supplementary Figs. 6, 7 and 15). As 

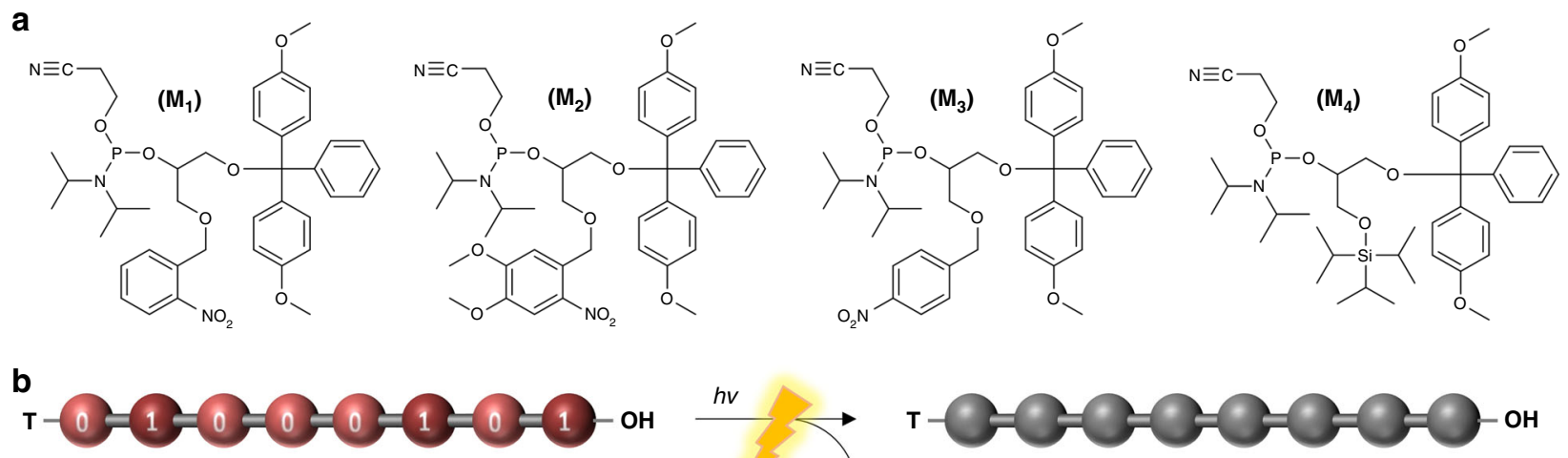

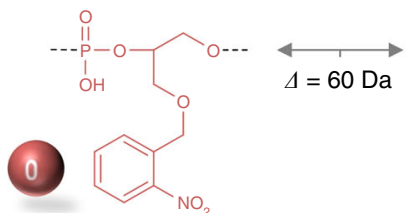

289.0 Da

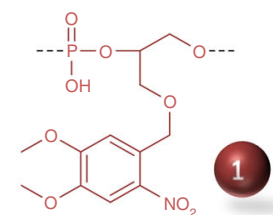

$349.1 \mathrm{Da}$

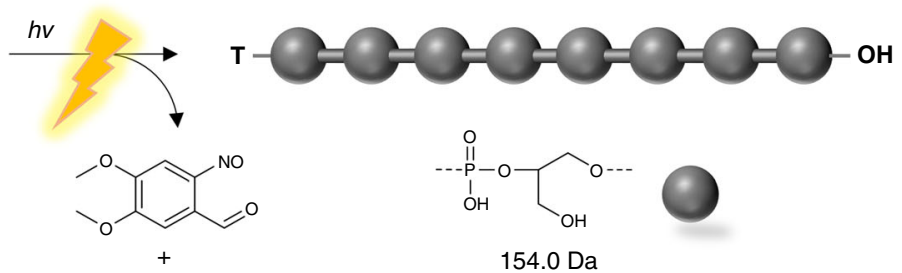

c

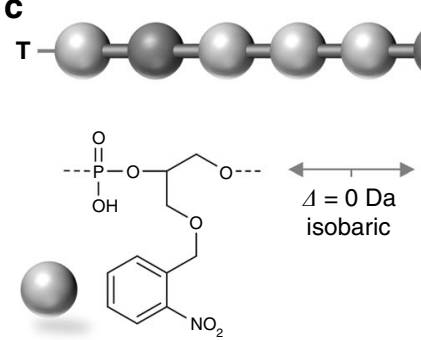

$289.0 \mathrm{Da}$

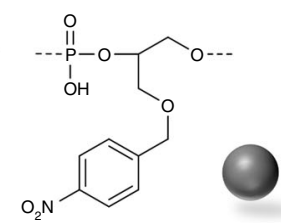

$289.0 \mathrm{Da}$ on

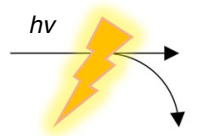

$1 C^{N O}$

154.0 Da

d

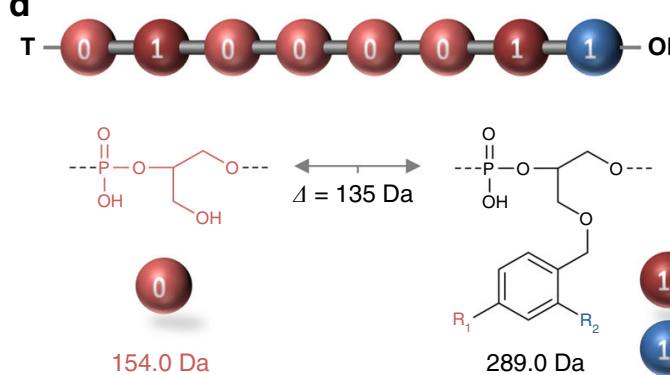

154.0 Da

289.0 Da

(1) $\mathrm{R}_{1}=\mathrm{NO}_{2}, \mathrm{R}_{2}=\mathrm{H}$
(1) $\mathrm{R}_{1}=\mathrm{H}, \mathrm{R}_{2}=\mathrm{NO}_{2}$

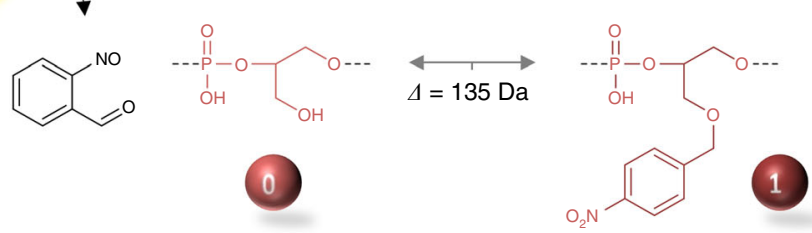

154.0 Da
289.0 Da

Fig. 1 Monomer and polymer design. a Molecular structures of the different phosphoramidite monomers that were synthesized and used in the present work. $\mathbf{b}$ Strategy for the preparation of photo-erasable digital polymers. In this case, monomers $\mathbf{M 1}$ and $\mathbf{M 2}$ are used as 0- and 1-bits, respectively. These monomers have different molar mass and therefore allow construction of digital sequences that can be decoded by MS/MS. Upon light irradiation, both 0 and 1 units are photo-cleaved, thus leading to a non-decodable homopolymer (depicted in gray). c Strategy for the preparation of polymers containing hidden messages. In this case, isobaric monomers $\mathbf{M 1}$ and $\mathbf{M 3}$ are used as an invisible binary ink, which lead to MS/MS non-decodable sequences. Light is then used as a revealer. Photo-irradiation cleaves selectively ortho-nitrobenzyl units, thus leading to a MS/MS decodable binary sequence. $\mathbf{d}$ Strategy for photo-induced site-directed mutations. In this case, the polymers are constructed using monomers M1, M3, and M4. After TIPS deprotection, the formed digital polymer contains isobaric 1-bits (depicted in red and blue). Light irradiation allows selective $1 \rightarrow 0$ mutation of a single type of 1 unit (i.e. only the blue one). The letter $\mathbf{T}$ symbolizes a terminal thymidine nucleoside unit in panels $\mathbf{b}$, $\mathbf{c}$, and $\mathbf{d}$

expected, no digital information could be found in this polymer (Supplementary Fig. 16). Comparable results were obtained with P2-P5 (Supplementary Figs. 17-24). Interestingly, the MS relative abundance of the low molecular weight by-products formed upon photo-exposure (Supplementary Figs. 6, 7 and 15) was found to be related to $0 / 1$ comonomer composition in the original copolymers P1-P5 (Supplementary Fig. 25). It shall also be remarked that the irradiated poly(phosphodiester)s contain pendant $\mathrm{OH}$-groups and, if need be, may be further degraded via a hydrolysis mechanism similar to the one of $\mathrm{RNA}^{34}$.
Digital polymers containing photo-revealable sequences. Monomers M1 and M3 were then used to build oligomers containing light-revealable information sequences (Supplementary Table 2). In order to confirm that polymers containing $p$-nitrobenzyl ether units are not photo-sensitive, homopolymer $\mathbf{H 3}$ was first synthesized using monomer M3 and characterized. HPLC (Supplementary Fig. 26) and ${ }^{1} \mathrm{H}$ NMR (Supplementary Fig. 27) measurements indicated synthesis of a uniform molecule, thus validating that M3 leads to high-yields coupling steps in solidphase iterative synthesis. Furthermore, as shown by MS 
a
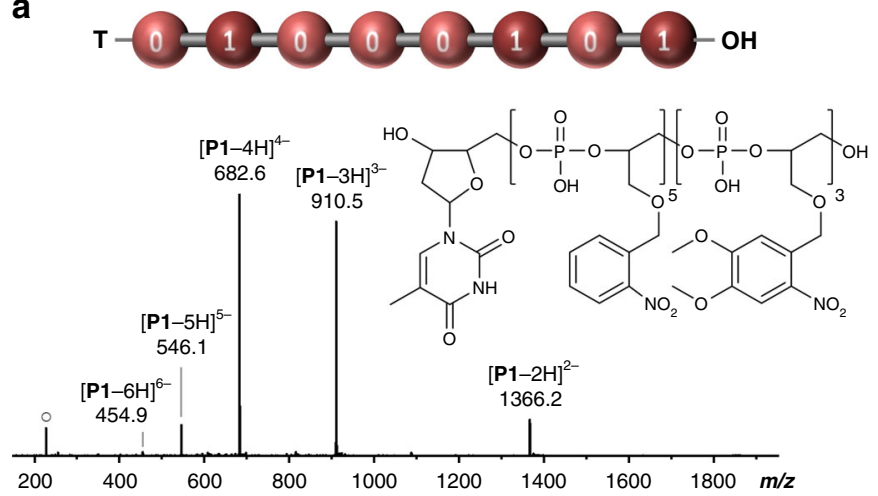

b
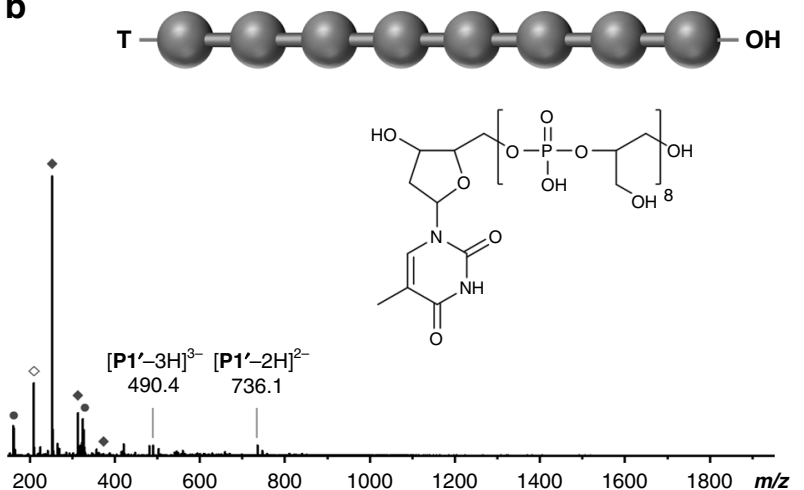

$\mathbf{C}$

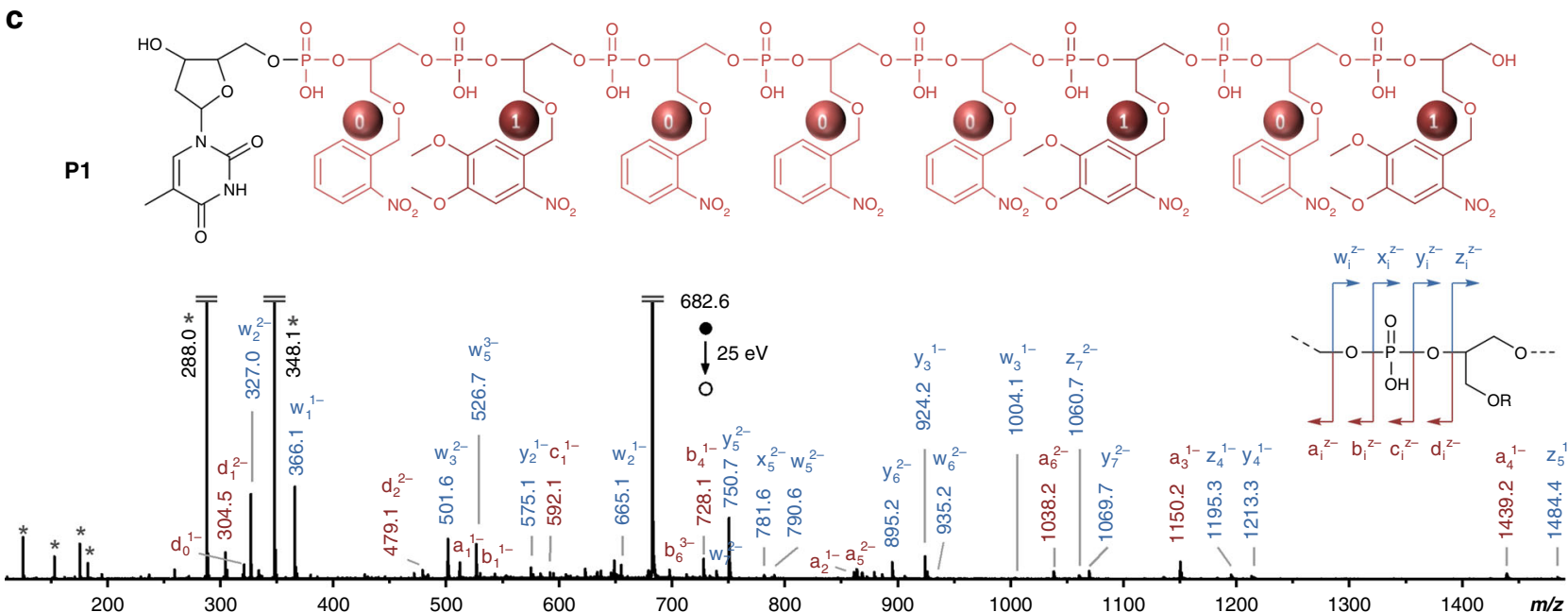

Fig. 2 Example of a photo-erasable digital polymer. ESI-HRMS spectra obtained in the negative ion mode for polymer P1 before (a) and after (b) light exposure. Open and full dark gray circles indicate clusters of trifluoroacetic acid and trichloroacetic acid, respectively. Open and full dark gray diamonds indicate photo-deprotection by-products. See Supplementary Figs. 6, 7 and 15 for interpretation. c MS/MS sequencing of the coded polymer P1 before photo-erasing. This spectrum was obtained by collision-induced dissociation of the $[\mathbf{P 1}-4 \mathrm{H}]^{4-}$ precursor ion. The inset schematizes the fragmentation pattern of a phosphate repeat unit. Dark gray stars indicate secondary fragments including deprotonated repeat units at $\mathrm{m} / \mathrm{z} 288.0$ and $\mathrm{m} / \mathrm{z} 348.1$

(Supplementary Fig. 28), the molecular structure of this polymer remained unchanged before and after photo-irradiation, and MS/ MS data confirmed the expected monotonic sequence of $\mathbf{H 3}$ (Supplementary Fig. 29). Based on these results, a series of coded oligomers P6-P11 containing different information sequences was prepared and characterized by HPLC (Supplementary Fig. 26), ${ }^{1} \mathrm{H}$ NMR spectroscopy (Supplementary Figs. 30-35), ${ }^{31} \mathrm{P}$ NMR spectroscopy (data not shown), and mass spectrometry. All these copolymers were photo-irradiated at $\lambda=365 \mathrm{~nm}$, thus leading to modified structures $\mathbf{P 6 ^ { \prime }}-\mathbf{P} \mathbf{1} \mathbf{1}^{\prime}$. Figure 3 compares the ESI-HRMS spectra obtained for P10, which contains a monomer sequence composed of five $p$-nitrobenzyl and three $o$-nitrobenzyl units, and the corresponding photo-irradiated oligomer P10'. The dominating species observed before irradiation has a molar mass of $2554 \mathrm{Da}$, whereas after light exposure an oligomer of $2149 \mathrm{Da}$ is observed. The mass difference of $405 \mathrm{Da}$ (i.e., $3 \times 135 \mathrm{Da}$ ) observed between both species corresponds to the release of three nitrobenzyl moieties. This suggests that the $o$-nitrobenzyl units are selectively and quantitatively cleaved from the polymer backbone upon irradiation. Moreover, before irradiation, MS/MS sequencing of P10 (Supplementary Fig. 36) evidenced a monotonic sequence, in which isobaric $o$-nitrobenzyl and $p$-nitrobenzyl units cannot be distinguished from another. The sequence can also not be decrypted by ${ }^{1} \mathrm{H}$ NMR spectroscopy (Supplementary Fig. 34), which only gives rough information about ortho/para comonomer composition. Yet, after photo-exposure, the digital sequence 01110011 can be extracted from the MS/MS spectrum of P10', as shown in Fig. $3 \mathrm{c}$ and Supplementary Table 5. These results confirm that monomers $\mathbf{M} 1$ and $\mathbf{M} 3$ can be efficiently used as an invisible binary ink to encrypt synthetic digital polymers. Comparable results were obtained with all other copolymers of the series, namely P6-P9 and P11 (Supplementary Figs. 37-46).

Site-directed photo-mutations. The strategy allowing sitedirected mutations in synthetic polymers was then examined. A photo-mutable poly(phosphodiester) was synthesized using monomers M1, M3, and M4 (Supplementary Table 3). M4 contains two $\mathrm{OH}$ functions that are orthogonally protected by 4,4'-dimethoxytrityl (DMT) and TIPS groups. The DMTprotected functions are selectively deprotected and reacted in stepwise phosphoramidite protocols, while the TIPS-protected pendant groups remain intact. After performing solid-phase synthesis, the TIPS groups are removed, thus resulting in a digital polymer in which $\mathrm{OH}$-functional side groups represents 0-bits while isobaric monomers $\mathbf{M} 1$ and $\mathbf{M} 3$ both code for 1-bits. Using this language, the ASCII sequence 01000011, coding for the letter $\mathrm{C}$, was stored in copolymer P12. The formed polymer was characterized by HPLC (Supplementary Fig. 47), 
a
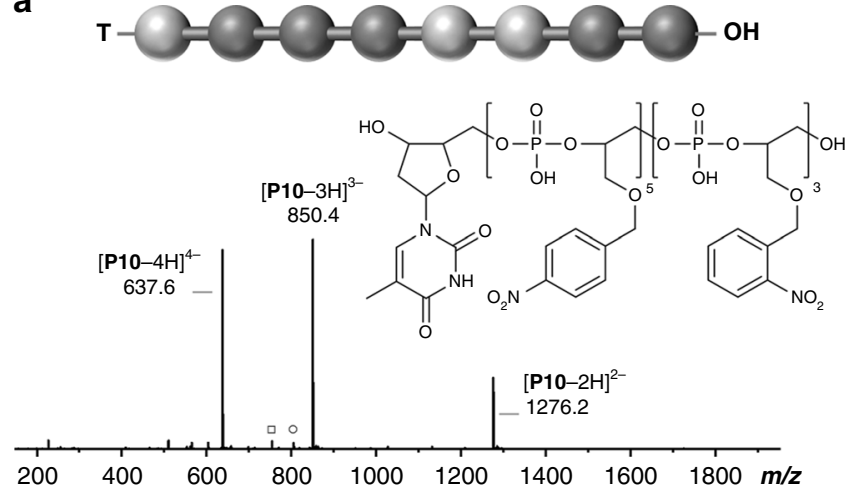

b
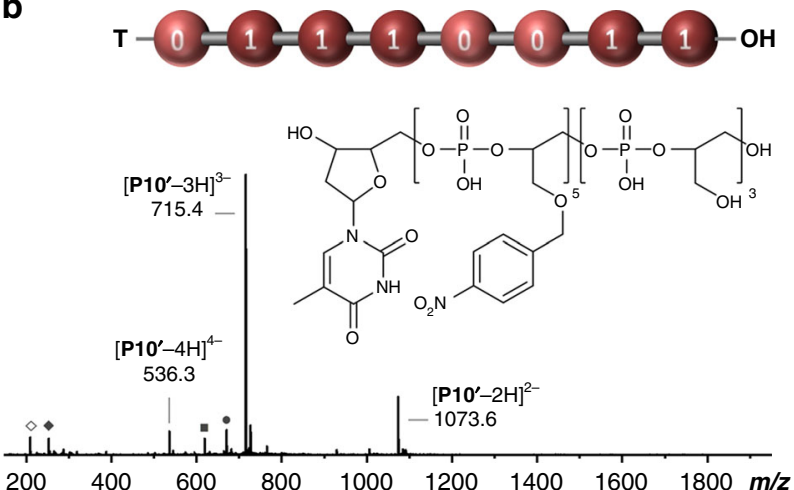

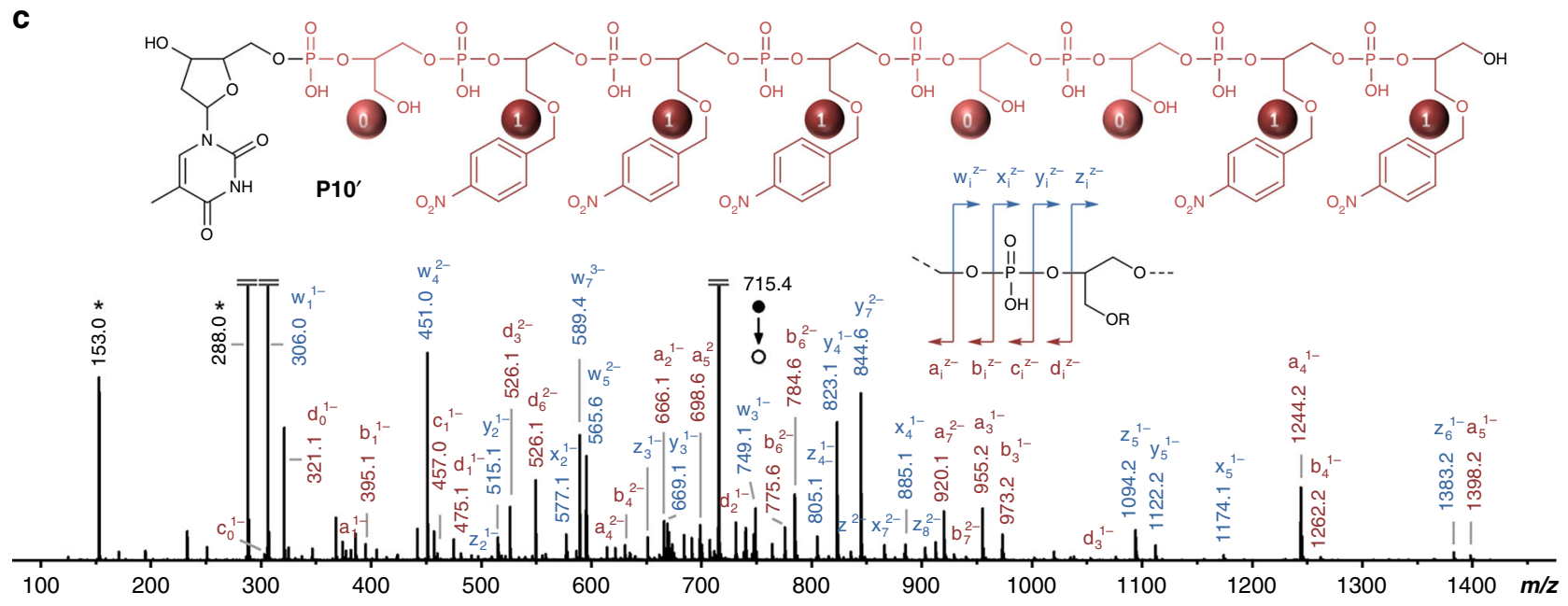

Fig. 3 Characterization of a digital polymer coded with an invisible monomer ink. ESI-HRMS spectra obtained in the negative ion mode for polymer P10 before (a) and after (b) light exposure. Squares and circles indicate synthesis impurities. Open and full dark gray diamonds indicate photo-deprotection byproducts. See Supplementary Fig. 6 for interpretation. c MS/MS sequencing of the irradiated polymer P10'. This spectrum was obtained by collisioninduced dissociation of the $\left[\mathbf{P} 1 \mathbf{1}^{\prime}-3 \mathrm{H}\right]^{3-}$ precursor ion. The inset schematizes the fragmentation pattern of a phosphate repeat unit. Dark gray stars indicate secondary fragments including deprotonated repeat units at $\mathrm{m} / z 153.0$ and $\mathrm{m} / \mathrm{z} 288.0$

${ }^{1} \mathrm{H}$ NMR spectroscopy (Supplementary Fig. 48), and ESI-MS (Supplementary Fig. 49). These measurements evidenced formation of a uniform molecule, in which all TIPS group have been removed. In copolymer P12, only one M1 unit is photo-labile and consequently a target site for directed photo-mutation. Upon photo-exposure, M1 loses its $o$-nitrobenzyl moiety, thus resulting in the formation of a 0 -bit (i.e. $1 \rightarrow 0$ mutation). As a consequence, the photo-modified polymer P12' contains the ASCII sequence 01000010 coding for the letter B. Supplementary Fig. 49 and Fig. 4 compare the ESI-MS and MS/MS sequencing data that were acquired for $\mathbf{P 1 2}$ before and after photo-irradiation. For clarity, only one series of fragments (noted $\mathrm{w}_{\mathrm{i}}{ }^{\mathrm{Z}}$ ) ) is highlighted in Fig. 4, whereas the full interpretation of the spectra can be found in Supplementary Table 6 . These results clearly evidence that the $1 \rightarrow 0$ mutation occurred and led to a modified information sequence. When a single M1 site is mutated, the overall molar mass of the oligomer shall decrease from 1879 to $1744 \mathrm{Da}$ (i.e. $-135 \mathrm{Da})$, which is what was observed in ESI-MS. Moreover, the fact that the molar mass of the MS/MS fragment $\mathrm{w}_{1}{ }^{1-}$ decreases of $135 \mathrm{Da}$ after irradiation (Fig. 4) indicates unequivocally sitedirected mutation. Since the mutation site is located at the extremity of the sequence in the studied example, the mass decrease of $135 \mathrm{Da}$ is also echoed in all ions of the $\mathrm{w}_{\mathrm{i}}^{\mathrm{z}-}$ fragment series, as highlighted in Fig. 4. This concept is also applicable to longer information sequences. The atomic symbol of copper that is $\mathrm{Cu}$ was ASCII-encoded in copolymer P13 using M1, M3, and
M4 (Supplementary Table 3 ). In this sequence, a single $1 \rightarrow 0$ photo-mutation site was implemented at the seventh monomer position, starting from the thymidine end-group. Thus, upon photo-irradiation, the information sequence is transformed into the ASCII-encoded atomic symbol of gold Au (Supplementary Figs. 50, 51 and 52 and Supplementary Tables 3, 7 and 8).

\section{Discussion}

The experimental results described in this article evidence that the information sequences of synthetic polymers can be easily manipulated by light. Various types of sequence modification (i.e. erasing, revealing, mutation) can be attained using a rather simple set of monomers. As already specified above, the concepts described herein are not restricted to digital poly(phosphodiester)s and can possibly be transposed to many other types of information-containing macromolecules ${ }^{3}$. Overall, these results open up interesting avenues for the design of functional polymer materials. For instance, photo-erasable polymers are interesting structures for data storage applications; e.g., for the development of polymer-based digital micro-arrays ${ }^{3}$. Indeed, such polymers could be exploited to erase specific information zones in a $2 \mathrm{D}$ micropattern ${ }^{35}$. Polymers containing photo-revealable information sequences could be of great relevance for anti-counterfeiting applications $^{36}$. Indeed, beyond standard monomer sequence encryption ${ }^{1}$, the fact that monomer sequences can be hidden and revealed gives an additional level of security and secrecy to 

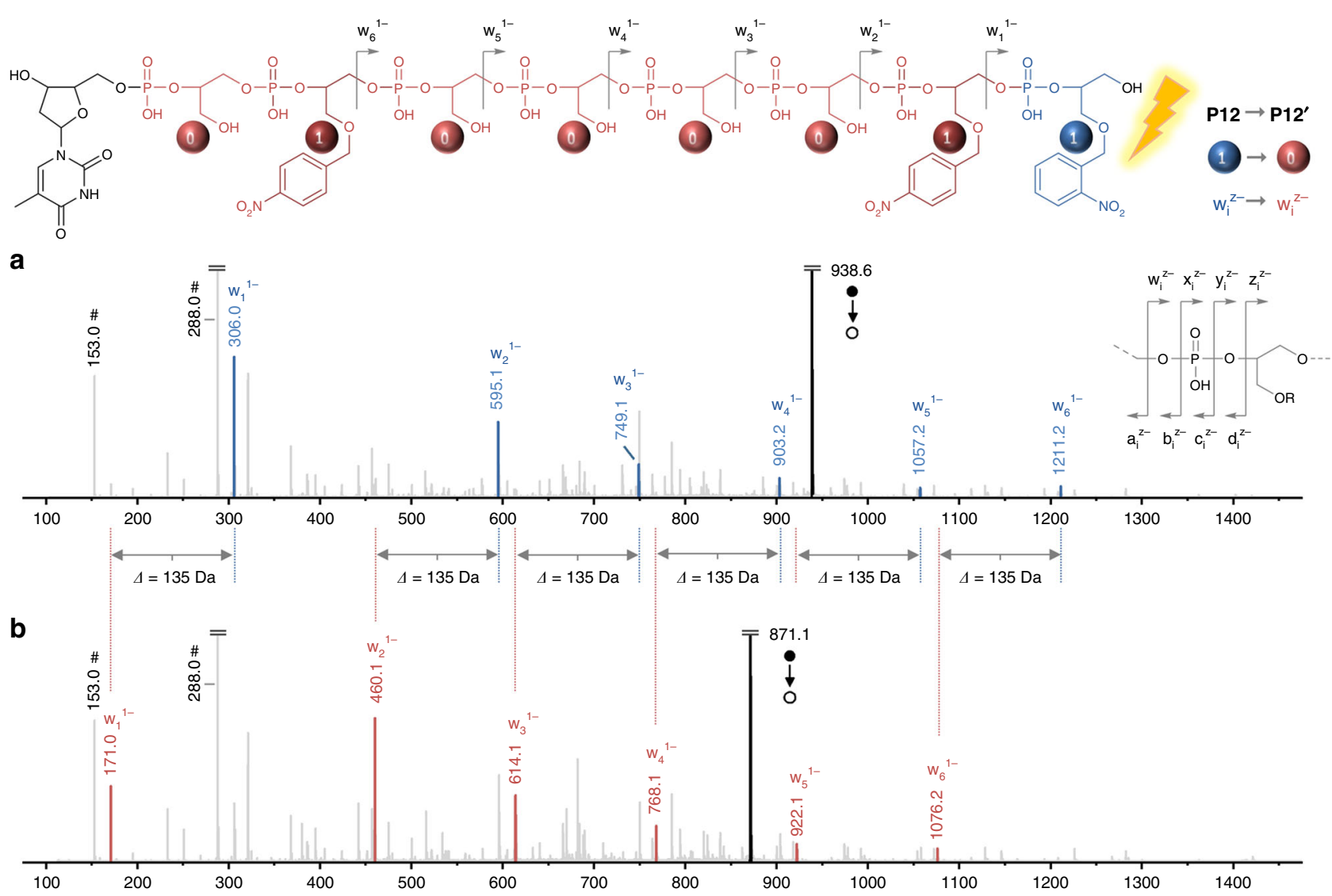

Fig. 4 Photo-induced sequence mutation. MS/MS sequencing spectra obtained for polymer P12 before (a) and after (b) light exposure. The top and bottom spectra were obtained by collision-induced dissociation of the $[\mathbf{P} 12-2 \mathrm{H}]^{2-}$ and $\left[\mathbf{P 1 2}^{\prime}-2 \mathrm{H}\right]^{2-}$ precursor ions, respectively. In these conditions, a phosphate repeat unit leads to different fragments, as indicated by the gray fragmentation pattern on the right side of panel $\mathbf{a}$. However, for clarity, only $\mathrm{w}_{\mathrm{i}}^{\mathrm{z}-\mathrm{fragments}}$ are highlighted in this figure. The corresponding peaks were intentionally thickened and colored (blue before- and red after irradiation) with the help of the Origin software. All other fragments are intentionally displayed in light gray. A detailed interpretation of all peaks can be found in Supplementary Table 6 . Black hashtags indicate deprotonated repeat units at $\mathrm{m} / \mathrm{z} 153.0$ and $\mathrm{m} / \mathrm{z} 288.0$

macromolecular taggants. Perhaps even more importantly, it was shown in this work that specific sequence mutations can be induced in synthetic macromolecules. Such an effect can be used to tune the meaning of polymer-stored information sequences, as evidenced herein. Yet, beyond primary structure modification, site-directed mutations could be used to induce conformational changes, to trigger latent functions, or to generate an evolutionary behavior in synthetic macromolecules.

\section{Methods}

Materials and reagents. Acetic acid (99.8\%, Fischer Chemical), acetone (Carlo Erba), anhydrous acetonitrile ( $99.8 \%$, anh. MeCN, Sigma-Aldrich), aqueous ammonia (28 w\% $\mathrm{NH}_{3}$ in $\mathrm{H}_{2} \mathrm{O}$, VWR), ammonium chloride (99.5\%, VWR), carbon tetrabromide $\left(99 \%, \mathrm{CBr}_{4}, \mathrm{TCI}\right), 2$-cyanoethyl- $N, N$-diisopropylchlorophosphoramidite (97\%, ABCR), cyclohexane (Carlo Erba), anhydrous dichloromethane (99.8\%, anh. DCM, cont. amylene as a stabilizer, Sigma-Aldrich), $N, N$-diisopropylethylamine ( $>99.0 \%$, DIPEA, TCI), 4,4'-dimethoxytrityl chloride (DMTr-Cl, ChemGenes), ethyl acetate (EtOAc, Carlo Erba), glycerol (1,2,3-propanetriol, cont. water, Merck), anhydrous methanol (99.8\%, anh. $\mathrm{MeOH}$, SigmaAldrich), aqueous methylamine (40 w\% $\mathrm{MeNH}_{2}$ in $\mathrm{H}_{2} \mathrm{O}$, Fluka), methyllithium (1.6 $\mathrm{M}$ in $\mathrm{Et}_{2} \mathrm{O}$, Sigma-Aldrich), molecular sieves (3 $\AA$, Merck), 2-nitrobenzyl bromide (98\%, Alfa Aesar), 4-nitrobenzyl bromide (97\%, Alfa Aesar), 4,5-dimethoxy-2-nitrobenzaldehyde (98\%, Alfa Aesar), para-toluenesulfonic acid monohydrate (99\%, Sigma-Aldrich), anhydrous pyridine $(99.8 \%$, anh. pyr, SigmaAldrich), silica gel (high-purity grade, pore size $60 \AA$, 230-400 mesh, for flash chromatography, $\mathrm{SiO}_{2}$, Fluka), sodium borohydride ( $98 \%$, Aldrich), sodium chloride (for brine solution, ESCO), sodium hydride (60 w\% suspension in mineral oil, Aldrich), anhydrous sodium sulfate (99.6\%, VWR), anhydrous toluene (99.8\%, anh. toluene, Sigma-Aldrich), triisopropylsilyl chloride (97\%, TIPSCl, SigmaAldrich), triethylamine trihydrofluoride (98\%, $\mathrm{Et}_{3} \mathrm{~N} .3 \mathrm{HF}$, Sigma-Aldrich), triethylamine (97\%, $\mathrm{Et}_{3} \mathrm{~N}$, Acros Organics), and triphenylphosphine $\left(\mathrm{PPh}_{3}, 95 \%, \mathrm{TCI}\right)$ were used as received without further purification. (2,2-Dimethyl-1,3-dioxolan-4yl)methanol and 4,5-dimethoxy-2-nitrobenzyl alcohol were synthesized following published procedures ${ }^{37,38}$. Reagents for automated phosphoramidite synthesis: anhydrous acetonitrile (phosphoramidite diluent \& dry washings, ChemGenes), acetonitrile ( $\geq 99.9 \%$, washings, Roth), activation reagent ( $0.25 \mathrm{M}$ 5-ethylthio tetrazole in $\mathrm{MeCN}$, ChemGenes), Cap A (acetic anhydride/pyridine/THF, ChemGenes), Cap B (10\% N-methylimidazole in THF, ChemGenes), DMT removal reagent ( $3 \mathrm{w} \%$ TCA in DCM, Roth), drying traps (small, 10-15 mL, ChemGenes), dT-CPG 1000 ( $1 \mu \mathrm{mol}$ in cartridge, $1000 \AA$ pore size, Glen Research), oxidizer (0.02 $\mathrm{M}$ iodine/pyridine/ $\mathrm{H}_{2} \mathrm{O} / \mathrm{THF}$, ChemGenes) were used as received.

Synthesis of phosphoramidite monomer M1. Monomer M1 was synthesized in four steps as shown in Supplementary Fig. 53. Synthesis details are described as follows. 2,2-dimethyl-4-(((2-nitrobenzyl)oxy)methyl)-1,3-dioxolane 1 . To a stirred solution of (2,2-dimethyl-1,3-dioxolan-4-yl)methanol ( $801 \mathrm{mg}, 6.1 \mathrm{mmol}, 1.2 \mathrm{eq}$.) and 2-nitrobenzyl bromide ( $1088 \mathrm{mg}, 5.0 \mathrm{mmol}, 1.0$ eq.) in $40 \mathrm{~mL} \mathrm{MeCN}$ (anh.) at $0{ }^{\circ} \mathrm{C}$ was added $\mathrm{NaH}$ (479 mg, $60 \mathrm{w} \%, 12.0 \mathrm{mmol}, 2.4$ eq.) at $0^{\circ} \mathrm{C}$ under argon. The mixture was stirred for $30 \mathrm{~min}$ at $0{ }^{\circ} \mathrm{C}$. Then, it was allowed to reach $\mathrm{RT}$ and the solvent was removed. Fifty milliliters $\mathrm{NH}_{4} \mathrm{Cl}$ (aq., sat.) was added and it was extracted with EtOAc $(3 \times 50 \mathrm{~mL})$. The combined organic layer was washed with brine $(2 \times$ $50 \mathrm{~mL}$ ), dried over $\mathrm{Na}_{2} \mathrm{SO}_{4}$, filtered, and the solvent was removed. The yellow crude oil was purified by column chromatography $\left(\mathrm{SiO}_{2}\right.$ vs $10 \mathrm{v} \% \rightarrow 20 \mathrm{v} \%$ EtOAc in cyclohexane) to obtain $658 \mathrm{mg}(2.5 \mathrm{mmol}, 49 \%)$ of 1 as a pale yellow oil. HRMS $\mathrm{m} / z$ : $[\mathrm{M}+\mathrm{H}]^{+}$calculated for $\mathrm{C}_{13} \mathrm{H}_{18} \mathrm{NO}_{5}+268.1179$; found $268.1181 ;{ }^{1} \mathrm{H}$ NMR (400.1 $\left.\mathrm{MHz}, \mathrm{CDCl}_{3}, \delta, \mathrm{ppm}\right): 1.38(\mathrm{~s}, 3 \mathrm{H}), 1.44(\mathrm{~s}, 3 \mathrm{H}), 3.60-3.69(\mathrm{~m}, 2 \mathrm{H}), 3.79(\mathrm{~m}, 1 \mathrm{H})$, $4.10(\mathrm{~m}, 1 \mathrm{H}), 4.36(\mathrm{~m}, 1 \mathrm{H}), 4.96(\mathrm{~s}, 2 \mathrm{H}), 7.42-7.47(\mathrm{~m}, 1 \mathrm{H}, \mathrm{ArH}), 7.62-7.67(\mathrm{~m}, 1 \mathrm{H}$, $\mathrm{ArH}), 7.80(\mathrm{~m}, 1 \mathrm{H}), 8.06(\mathrm{~m}, 1 \mathrm{H}) ;{ }^{13} \mathrm{C} \mathrm{NMR}\left(100.6 \mathrm{MHz} \mathrm{CDCl}_{3}, \delta, \mathrm{ppm}\right): 25.5,26.8$, 66.7, 70.1, 72.2, 74.7, 109.6, 124.7, 128.1, 128.8, 133.7, 134.8, 147.3. 3-((2-nitrobenzyl) oxy)propane-1,2-diol 2. Dioxolan $1(860 \mathrm{mg}, 3.2 \mathrm{mmol})$ was dissolved in $43 \mathrm{~mL}$ $\mathrm{AcOH}$ (aq., $10 \mathrm{w} \%$ ) and the solution was stirred at $60^{\circ} \mathrm{C}$ for $5 \mathrm{~h}$. The mixture was extracted with EtOAc $(3 \times 50 \mathrm{~mL})$. The combined organic layer was dried over $\mathrm{Na}_{2} \mathrm{SO}_{4}$, filtered, and the solvent was removed. The crude was purified by column chromatography $\left(\mathrm{SiO}_{2}\right.$ vs $50 \mathrm{v} \% \rightarrow 100 \mathrm{v} \%$ EtOAc in hexane) to obtain $680 \mathrm{mg}$ 
$(3.0 \mathrm{mmol}, 93 \%)$ of the product as a yellow oil. HRMS $\mathrm{m} / \mathrm{z}:[\mathrm{M}+\mathrm{Na}]^{+}$calculated for $\mathrm{C}_{10} \mathrm{H}_{13} \mathrm{NO}_{5} \mathrm{Na}^{+}$250.0686; found 250.0679; ${ }^{1} \mathrm{H}$ NMR $\left(400.1 \mathrm{MHz}, \mathrm{CDCl}_{3}, \delta, \mathrm{ppm}\right)$ : $2.21(\mathrm{bs}, 2 \mathrm{H}), 3.63-3.78(\mathrm{~m}, 4 \mathrm{H}), 3.94-3.99(\mathrm{~m}, 1 \mathrm{H}), 4.92(\mathrm{~s}, 2 \mathrm{H}), 7.43-7.49(\mathrm{~m}, 1 \mathrm{H})$,

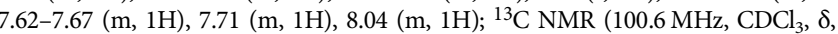
ppm): 63.9, 70.1, 70.9, 72.5, 124.8, 128.3, 128.9, 133.7, 134.3, 147.5. 1-(bis(4-methoxyphenyl)(phenyl)methoxy)-3-((2-nitrobenzyl)oxy)propan-2-ol 3. To a stirred solution of diol $2(241 \mathrm{mg}, 1.1 \mathrm{mmol}, 1.0$ eq.) in $5 \mathrm{~mL} \mathrm{THF}$ (anh.):pyridine (anh.) =3: 2 (v:v) 4,4'-dimethoxytrityl chloride $(360 \mathrm{mg}, 1.1 \mathrm{mmol}, 1.0 \mathrm{eq}$.) was added in three intervals of each $40 \mathrm{~min}$ at RT under argon atmosphere and stirred overnight. The solvent was removed, $20 \mathrm{~mL} \mathrm{NaHCO}_{3}$ (sat., aq.) was added, and it was extracted with $\operatorname{EtOAc}(3 \times 50 \mathrm{~mL})$. The combined organic layer was washed with brine $(2 \times 25 \mathrm{~mL})$, dried over $\mathrm{Na}_{2} \mathrm{SO}_{4}$, filtered, and the solvent was removed. The yellow crude oil was purified by column chromatography $\left(\mathrm{SiO}_{2}\right.$ vs $20 \mathrm{v} \% \rightarrow 33 \mathrm{v} \%$ EtOAc in cyclohexane $+3 \mathrm{v} \%$ DIPEA) to obtain $493 \mathrm{mg}(0.9 \mathrm{mmol}, 88 \%)$ of the product as a yellowish foam. HRMS $m / z:[\mathrm{M}+\mathrm{Na}]^{+}$calculated for $\mathrm{C}_{31} \mathrm{H}_{31} \mathrm{NO}_{7} \mathrm{Na}^{+}$552.1993; found, 552.1996; ${ }^{1} \mathrm{H}$ NMR $\left(400.1 \mathrm{MHz}, \mathrm{CDCl}_{3}, \delta, \mathrm{ppm}\right): 2.39(\mathrm{~m}, 1 \mathrm{H}), 3.27(\mathrm{~m}, 2 \mathrm{H})$, 3.66-3.71 (m, 2H), $3.78(\mathrm{~s}, 6 \mathrm{H}), 4.02(\mathrm{~m}, 1 \mathrm{H}), 4.91(\mathrm{~s}, 2 \mathrm{H}), 6.82(\mathrm{~m}, 4 \mathrm{H}), 7.18-7.23$ $(\mathrm{m}, 1 \mathrm{H}), 7.27-7.34(\mathrm{~m}, 6 \mathrm{H}), 7.40-7.46(\mathrm{~m}, 3 \mathrm{H}), 7.57-7.63(\mathrm{~m}, 1 \mathrm{H}), 7.69(\mathrm{~m}, 1 \mathrm{H}), 8.07$ (m, $1 \mathrm{H}) .{ }^{13} \mathrm{C}$ NMR $\left(100.6 \mathrm{MHz}, \mathrm{CDCl}_{3}, \delta\right.$, ppm): 55.3, 64.4, 70.0, 70.1, 72.6, 86.3, $113.3,124.8,126.9,128.0,128.1,128.2,128.7,130.2,133.8,135.0,136.0,144.9,147.2$ 158.6. 1-(bis(4-methoxyphenyl)(phenyl)methoxy)-3-((2-nitrobenzyl)oxy)propan-2yl (2-cyanoethyl) diisopropylphosphoramidite M1. $1136 \mathrm{mg}$ of 3 (2.1 mmol, 1.0 eq.) were dissolved in $10 \mathrm{~mL}$ anhydrous DCM. Then, DIPEA $(1660 \mathrm{mg}, 13.7 \mathrm{mmol}, 6.0$ eq.), molecular sieves ( $3 \AA$ ) and 2-cyanoethyl- $N, N$-diisopropylchlorophosphoramidite $\left(581 \mathrm{mg}, 2.5 \mathrm{mmol}, 1.15 \mathrm{eq}\right.$.) were added under argon atmosphere at $0^{\circ} \mathrm{C}$. The reaction mixture was stirred at $0{ }^{\circ} \mathrm{C}$ for $30 \mathrm{~min}$ and then allowed to reach RT. DCM was removed and the residue was purified by column chromatography $\left(\mathrm{SiO}_{2}\right.$ vs $33 \mathrm{v} \%$ EtOAc in cyclohexane $+3 \mathrm{v} \%$ DIPEA) to obtain $1508 \mathrm{mg}(2.1 \mathrm{mmol}, 97 \%)$ of $\mathrm{M1}$ as a yellowish foam. HRMS $m / z:[\mathrm{M}+\mathrm{H}]^{+}$calculated for $\mathrm{C}_{40} \mathrm{H}_{49} \mathrm{~N}_{3} \mathrm{O}_{8} \mathrm{P}^{+} 730.3252$; found 730.3250; ${ }^{1} \mathrm{H}$ NMR $\left(400.1 \mathrm{MHz}, \mathrm{CDCl}_{3}, \delta, \mathrm{ppm}\right): 1.04-1.20(\mathrm{~m}, 12 \mathrm{H})$, 2.42-2.60 (m, 2H), 3.18-3.37 (m, 2H), 3.50-3.65 (m, 2H), 3.69-3.89 (m, 4H), $3.78(\mathrm{~s}$, $6 \mathrm{H}), 4.20(\mathrm{~m}, 1 \mathrm{H}), 4.87-4.95(\mathrm{~m}, 2 \mathrm{H}), 6.77-6.84(\mathrm{~m}, 4 \mathrm{H}), 7.17-7.22(\mathrm{~m}, 1 \mathrm{H})$, $7.24-7.28(\mathrm{~m}, 2 \mathrm{H}), 7.30-7.36(\mathrm{~m}, 4 \mathrm{H}), 7.40-7.48(\mathrm{~m}, 3 \mathrm{H}), 7.54-7.62(\mathrm{~m}, 1 \mathrm{H})$ 7.70-7.76 (m, 1H), 8.05-8.10 (m, 1H); ${ }^{13} \mathrm{C}$ NMR (100.6 MHz, $\left.\mathrm{CDCl}_{3}, \delta, \mathrm{ppm}\right): 20.4$, 24.5, 24.7, 43.3, 55.3, 58.5, 63.9, 69.9, 72.1, 72.6, 86.1, 113.1, 117.7, 124.7, 126.8, 127.9, $128.3,128.4,128.7,130.2,133.7,135.5,136.2,145.0,147.0,158.5 ;{ }^{31}$ P NMR (161.9 $\left.\mathrm{MHz}, \mathrm{CDCl}_{3}, \delta, \mathrm{ppm}\right): 149.4$

Synthesis of phosphoramidite monomer M2. Monomer M2 was synthesized in four steps as shown in Supplementary Fig. 54. In the first step, (2,2-dimethyl-1,3dioxolan-4-yl)methanol was reacted with 4,5-dimethoxy-2-nitrobenzyl bromide. The latter compound was synthesized in one step as shown in Supplementary Fig. 53b. 4,5-dimethoxy-2-nitrobenzyl bromide 4. $\mathrm{PPh}_{3}(2620 \mathrm{mg}, 10.0 \mathrm{mmol}, 1.5$ eq.) was added at $0{ }^{\circ} \mathrm{C}$ and under argon atmosphere to a stirred solution of 4,5dimethoxy-2-nitrobenzyl alcohol (1424 mg, $6.7 \mathrm{mmol}, 1.0 \mathrm{eq}$.$) and \mathrm{CBr}_{4}(3324 \mathrm{mg}$, $10 \mathrm{mmol}$, 1.5 eq.) in $40 \mathrm{~mL}$ anhydrous THF. The reaction mixture was stirred overnight and then allowed to reach RT. After reaction, the mixture was filtered and evaporated. The crude was purified by column chromatography $\left(\mathrm{SiO}_{2}\right.$ vs $10 \mathrm{v}$ $\% \rightarrow 40 \mathrm{v} \%$ EtOAc in hexane) to obtain $1690 \mathrm{mg}(6.1 \mathrm{mmol}, 92 \%)$ of the product as a pale yellow crystalline solid. ${ }^{1} \mathrm{H} \mathrm{NMR}\left(400.1 \mathrm{MHz}, \mathrm{CDCl}_{3}, \delta, \mathrm{ppm}\right): 3.96(\mathrm{~s}, 3 \mathrm{H}$, $\left.\mathrm{ArOCH}_{3}\right), 4.00$ (s, 3H, $\left.\mathrm{ArOCH}_{3}\right), 4.87$ (s, $\left.2 \mathrm{H}, \mathrm{PhCH}_{2} \mathrm{Br}\right), 6.94$ (s, 1H, ArH), 7.67 (s, $1 \mathrm{H}, \overline{\mathrm{ArH}}) ;{ }^{13} \mathrm{C}$ NMR $\left(100 . \overline{\mathrm{MHz}}, \mathrm{CDCl}_{3}, \delta, \mathrm{ppm}\right): 30.2,56.6,56.7,108.7,113.8$ 127.6, 140.4, 149.1, 153.3. 4-((4,5-dimethoxy-2-nitrobenzyl)oxy)methyl)-2,2dimethyl-1,3-dioxolane 5. To a stirred solution of (2,2-dimethyl-1,3-dioxolan-4yl)methanol $\left(620 \mathrm{mg}, 4.7 \mathrm{mmol}, 1.0 \mathrm{eq}\right.$.) in $12 \mathrm{~mL} \mathrm{MeCN}$ (anh.) at $0^{\circ} \mathrm{C}, \mathrm{NaH}(226$ $\mathrm{mg}, 60 \mathrm{w} \%, 5.7 \mathrm{mmol}, 1.2 \mathrm{eq}$.) was added under argon atmosphere. The suspension was stirred $10 \mathrm{~min}$ at $0{ }^{\circ} \mathrm{C}$ and a solution of $4(1690 \mathrm{mg}, 6.1 \mathrm{mmol}, 1.3 \mathrm{eq}$.) dissolved in $5 \mathrm{~mL}$ DCM (anh.) and $5 \mathrm{~mL} \mathrm{MeCN}$ (anh.) was added. The reaction mixture was stirred for $15 \mathrm{~min}$ at $0{ }^{\circ} \mathrm{C}$ and for further $3 \mathrm{~h}$ allowed to reach RT. The solvent was removed, $20 \mathrm{~mL} \mathrm{H}_{2} \mathrm{O}$ was added and it was extracted with DCM $(3 \times$ $50 \mathrm{~mL})$. The combined organic layer was washed with brine $(1 \times 50 \mathrm{~mL})$, dried over $\mathrm{Na}_{2} \mathrm{SO}_{4}$, filtered and the solvent was removed. The orange crude solid was purified by column chromatography ( $\mathrm{SiO}_{2}$ vs $20 \mathrm{v} \% \rightarrow 30 \mathrm{v} \%$ EtOAc in hexane) to obtain $840 \mathrm{mg}(2.6 \mathrm{mmol}, 54 \%)$ of the product as a yellow solid. $1.5 \mathrm{mmol}$ of bromide 4 were also recovered. HRMS $m / z$ : $\left[\mathrm{M}+\mathrm{NH}_{4}\right]^{+}$calculated for $\mathrm{C}_{15} \mathrm{H}_{25} \mathrm{~N}_{2} \mathrm{O}_{7}{ }^{+}$ 345.1656; found 345.1657; ${ }^{1} \mathrm{H}$ NMR (400.1 MHz, $\left.\mathrm{CDCl}_{3}, \delta, \mathrm{ppm}\right): 1.39$ (s, 3H), 1 . $44(\mathrm{~s}, 3 \mathrm{H}), 3.68(\mathrm{~m}, 2 \mathrm{H}), 3.82(\mathrm{~m}, 1 \mathrm{H}), 3.95(\mathrm{~s}, 3 \mathrm{H}), 3.97(\mathrm{~s}, 3 \mathrm{H}), 4.10(\mathrm{~m}, 1 \mathrm{H}), 4.39$ $(\mathrm{m}, 1 \mathrm{H}), 4.98(\mathrm{~s}, 2 \mathrm{H}), 7.33(\mathrm{~s}, 1 \mathrm{H}), 7.71(\mathrm{~s}, 1 \mathrm{H}, \mathrm{ArH}) ;{ }^{13} \mathrm{C}$ NMR $(100.6 \mathrm{MHz}$, $\left.\mathrm{CDCl}_{3}, \delta, \mathrm{ppm}\right): 25.5,26.8,56.4,56.5,66.5,70.2,72.0,74.9,108.0,109.5,109.7$, 130.8, 139.3, 147.7, 153.9. 3-((4,5-dimethoxy-2-nitrobenzyl)oxy)propane-1,2-diol 6. $840 \mathrm{mg}$ of $5(2.6 \mathrm{mmol})$ was dissolved in $5 \mathrm{~mL}$ THF and $34 \mathrm{~mL} \mathrm{AcOH} \mathrm{(aq.,} 10 \mathrm{w}$ $\%$ ). The solution was stirred at $60^{\circ} \mathrm{C}$ for $2.5 \mathrm{~h}$. The mixture was extracted with EtOAc $(3 \times 50 \mathrm{~mL})$. The combined organic layer was dried over $\mathrm{Na}_{2} \mathrm{SO}_{4}$, filtered and the solvent was removed. The crude was purified by column chromatography $\left(\mathrm{SiO}_{2}\right.$ vs EtOAc) to obtain $720 \mathrm{mg}(2.5 \mathrm{mmol}, 98 \%)$ of the product as a yellow solid. HRMS $m / z:\left[\mathrm{M}+\mathrm{NH}_{4}\right]^{+}$calculated for $\mathrm{C}_{12} \mathrm{H}_{21} \mathrm{~N}_{2} \mathrm{O}_{7}+305.1343$; found, 305.1349; ${ }^{1} \mathrm{H}$ NMR (400.1 MHz, $\left.\mathrm{CD}_{3} \mathrm{OD}, \delta, \mathrm{ppm}\right): 3.56-3.69(\mathrm{~m}, 4 \mathrm{H}), 3.83-3.88(\mathrm{~m}, 1 \mathrm{H})$, $3.90(\mathrm{~s}, 3 \mathrm{H}), 3.97(\mathrm{~s}, 3 \mathrm{H}), 4.91(\mathrm{~s}, 2 \mathrm{H}), 7.43(\mathrm{~s}, 1 \mathrm{H}), 7.72(\mathrm{~s}, 1 \mathrm{H}) ;{ }^{13} \mathrm{C}$ NMR $(100.6$ $\mathrm{MHz}, \mathrm{CD}_{3} \mathrm{OD}, \delta$, ppm): $56.8,56.9,64.4,71.0,72.3,73.5,109.1,111.2,131.7,140.7$, 149.2, 155.3. 1-(bis(4-methoxyphenyl)(phenyl)methoxy)-3-((4,5-dimethoxy-2- nitrobenzyl)oxy)propan-2-ol 7. To a stirred solution of diol $6(670 \mathrm{mg}, 2.3 \mathrm{mmol}$, 1.0 eq.) in $10 \mathrm{~mL}$ THF (anh.):pyridine (anh.) =3:2 (v:v) 4,4'-dimethoxytrityl chloride $(790 \mathrm{mg}, 2.3 \mathrm{mmol}, 1.0$ eq.) was added in three intervals of each $40 \mathrm{~min}$ at RT, under argon atmosphere and stirred overnight. The solvent was removed, $20 \mathrm{~mL} \mathrm{NaHCO}_{3}$ (sat., aq.) were added and it was extracted with $\mathrm{EtOAc}(3 \times$ $50 \mathrm{~mL})$. The combined organic layer was washed with brine $(2 \times 50 \mathrm{~mL})$, dried over $\mathrm{Na}_{2} \mathrm{SO}_{4}$, filtered and the solvent was removed. The yellow crude oil was purified by column chromatography $\left(\mathrm{SiO}_{2}\right.$ vs $30 \mathrm{v} \% \rightarrow 50 \mathrm{v} \%$ EtOAc in cyclohexane $+3 \mathrm{v} \%$ DIPEA) to obtain $1050 \mathrm{mg}(1.8 \mathrm{mmol}, 76 \%)$ of the product as a yellowish foam. HRMS $m / z:[\mathrm{M}+\mathrm{Na}]^{+}$calculated for $\mathrm{C}_{33} \mathrm{H}_{35} \mathrm{NO}_{9} \mathrm{Na}^{+}$612.2204; found, 612.2203 ${ }^{1} \mathrm{H}$ NMR $\left(400.1 \mathrm{MHz}, \mathrm{CDCl}_{3}, \delta, \mathrm{ppm}\right): 2.43(\mathrm{~m}, 1 \mathrm{H}), 3.27(\mathrm{~m}, 2 \mathrm{H}), 3.65-3.73(\mathrm{~m}$ $2 \mathrm{H}), 3.77(\mathrm{~s}, 6 \mathrm{H}), 3.88(\mathrm{~s}, 3 \mathrm{H}), 3.95(\mathrm{~s}, 3 \mathrm{H}), 4.07(\mathrm{~m}, 1 \mathrm{H}), 4.92(\mathrm{~m}, 2 \mathrm{H}), 6.81(\mathrm{~m}$ $4 \mathrm{H}), 7.17-7.24(\mathrm{~m}, 2 \mathrm{H}), 7.27-7.33(\mathrm{~m}, 6 \mathrm{H}), 7.42(\mathrm{~m}, 2 \mathrm{H}), 7.71(\mathrm{~s}, 1 \mathrm{H}) ;{ }^{13} \mathrm{C}$ NMR $\left(100.6 \mathrm{MHz}, \mathrm{CDCl}_{3}, \delta, \mathrm{ppm}\right): 55.3,56.4,64.6,70.1,70.2,72.6,86.3,108.0,109.5$, $113.2,127.0,128.0,128.2,130.1,130.9,135.9,139.1,144.8,147.6,153.9,158.6 .1-$ (bis(4-methoxyphenyl)(phenyl)methoxy)-3-((4,5-dimethoxy-2-nitrobenzyl)oxy) propan-2-yl (2-cyanoethyl) diisopropylphosphoramidite M2. DIPEA $(584 \mathrm{mg}$, $4.5 \mathrm{mmol}, 6.0$ eq.) and molecular sieves $(3 \AA)$ were added at $0{ }^{\circ} \mathrm{C}$ under argon atmosphere to a solution of 7 ( $420 \mathrm{mg}, 0.7 \mathrm{mmol}, 1.0 \mathrm{eq}$.) in $5 \mathrm{~mL}$ anhydrous DCM. Then, 2-cyanoethyl- $\mathrm{N}, \mathrm{N}$-diisopropylchlorophosphoramidite $(189 \mathrm{mg}, 0.8 \mathrm{mmol}$, 1.12 eq.) was added. The reaction mixture was stirred at $0^{\circ} \mathrm{C}$ for $30 \mathrm{~min}$ and then allowed to reach RT. The solvent was removed and the residue purified by column chromatography $\left(\mathrm{SiO}_{2}\right.$ vs $30 \mathrm{v} \%$ EtOAc in cyclohexane $+3 \mathrm{v} \%$ DIPEA) to obtain $527 \mathrm{mg}(0.7 \mathrm{mmol}, 94 \%)$ of the product as a yellowish foam. HRMS $\mathrm{m} / \mathrm{z}:[\mathrm{M}+\mathrm{H}]^{+}$ calculated for $\mathrm{C}_{42} \mathrm{H}_{53} \mathrm{~N}_{3} \mathrm{O}_{10} \mathrm{P}^{+} 790.3463$; found $790.3471 ;{ }^{1} \mathrm{H}$ NMR $(400.1 \mathrm{MHz}$, $\left.\mathrm{CDCl}_{3}, \delta, \mathrm{ppm}\right): 1.04-1.20(\mathrm{~m}, 12 \mathrm{H}), 2.42-2.60(\mathrm{~m}, 2 \mathrm{H}), 3.17-3.34(\mathrm{~m}, 2 \mathrm{H})$, 3.50-3.67 (m, 2H), 3.70-3.92 (m, 4H), $3.77(\mathrm{~m}, 6 \mathrm{H}), 3.85(\mathrm{~m}, 3 \mathrm{H}), 3.95(\mathrm{~m}, 3 \mathrm{H})$, $4.24(\mathrm{~m}, 1 \mathrm{H}), 4.88-4.98(\mathrm{~m}, 2 \mathrm{H}), 6.75-6.83(\mathrm{~m}, 4 \mathrm{H}), 7.16-7.24(\mathrm{~m}, 2 \mathrm{H}), 7.27-7.35$ (m, 6H), 7.41-7.47 (m, 2H), $7.71(\mathrm{~m}, 1 \mathrm{H}) ;{ }^{13} \mathrm{C} \mathrm{NMR}\left(100.6 \mathrm{MHz}, \mathrm{CDCl}_{3}, \delta, \mathrm{ppm}\right)$ 20.3, 24.6, 43.3, 55.3, 56.4, 58.4, 64.1, 70.2, 72.5, 86.1, 107.8, 109.5, 113.1, 117.7, $126.8,127.8,128.3,130.2,131.3,136.1,138.8,145.0,147.5,153.9,158.5 ;{ }^{31} \mathrm{P}$ NMR $\left(161.9 \mathrm{MHz}, \mathrm{CDCl}_{3}, \delta, \mathrm{ppm}\right): 149.4$.

Synthesis of phosphoramidite monomer M3. Monomer M3 was synthesized in four steps as shown in Supplementary Fig. 55. Synthesis details are described as follows. 2,2-dimethyl-4-(((4-nitrobenzyl)oxy)methyl)-1,3-dioxolane $8.441 \mathrm{mg}$ of $\mathrm{NaH}\left(60 \mathrm{w} \%, 11.0 \mathrm{mmol}, 1.1 \mathrm{eq}\right.$.) was added at $0{ }^{\circ} \mathrm{C}$ and under argon atmosphere to a stirred solution of (2,2-dimethyl-1,3-dioxolan-4-yl)methanol (1328 mg, 10.0 mmol, 1.0 eq.) and 4-nitrobenzyl bromide ( $3247 \mathrm{mg}, 15.0 \mathrm{mmol}, 1.5 \mathrm{eq}$.$) in 40 \mathrm{~mL}$ of anhydrous $\mathrm{MeCN}$. The reaction mixture was stirred for $30 \mathrm{~min}$ at $0{ }^{\circ} \mathrm{C}$ and then allowed to reach RT for $30 \mathrm{~min}$. The reaction mixture was filtered. The solvent was removed from the filtrate and the crude directly purified by column chromatography $\left(\mathrm{SiO}_{2}\right.$ vs $10 \mathrm{v} \% \rightarrow 20 \mathrm{v} \%$ EtOAc in cyclohexane) to obtain $1077 \mathrm{mg}$ $(4.0 \mathrm{mmol}, 40 \%)$ of the product as a yellow oil. HRMS $m / z:[\mathrm{M}+\mathrm{H}]^{+}$calculated for $\mathrm{C}_{13} \mathrm{H}_{18} \mathrm{NO}_{5}{ }^{+}$268.1179; found, 268.1180; ${ }^{1} \mathrm{H}$ NMR (400.1 MHz, $\mathrm{CDCl}_{3}, \delta$ ppm): $1.38(\mathrm{~s}, 3 \mathrm{H}), 1.44(\mathrm{~s}, 3 \mathrm{H}), 3.53-3.64(\mathrm{~m}, 2 \mathrm{H}), 3.77(\mathrm{~m}, 1 \mathrm{H}), 4.09(\mathrm{~m}, 1 \mathrm{H})$, $4.34(\mathrm{~m}, 1 \mathrm{H}), 4.68(\mathrm{~s}, 2 \mathrm{H}), 7.51(\mathrm{~m}, 2 \mathrm{H}), 8.21(\mathrm{~m}, 2 \mathrm{H}) ;{ }^{13} \mathrm{C} \mathrm{NMR}(100.6 \mathrm{MHz}$, $\left.\mathrm{CDCl}_{3}, \delta, \mathrm{ppm}\right): 25.5,26.9,66.7,71.9,72.4,74.8,109.7,123.8,127.8,145.8,147.5$. 3 ((4-nitrobenzyl)oxy)propane-1,2-diol 9. $1030 \mathrm{mg}$ of $8(3.8 \mathrm{mmol})$ was dissolved in $50 \mathrm{~mL} \mathrm{AcOH}$ (aq., $10 \mathrm{w} \%$ ). The solution was stirred at $60^{\circ} \mathrm{C}$ for $2.5 \mathrm{~h}$. The mixture was extracted with EtOAc $(3 \times 55 \mathrm{~mL})$. The combined organic layer was dried over $\mathrm{Na}_{2} \mathrm{SO}_{4}$, filtered and the solvent was removed. The crude was purified by column chromatography $\left(\mathrm{SiO}_{2}\right.$ vs $\left.\mathrm{EtOAc}\right)$ to obtain $840 \mathrm{mg}(3.7 \mathrm{mmol}, 96 \%)$ of the product as a yellow oil. HRMS $m / z:[\mathrm{M}+\mathrm{Na}]^{+}$calculated for $\mathrm{C}_{10} \mathrm{H}_{13} \mathrm{NO}_{5} \mathrm{Na}^{+}$250.0686; found, 250.0687; ${ }^{1} \mathrm{H}$ NMR $\left(400.1 \mathrm{MHz}, \mathrm{CDCl}_{3}, \delta, \mathrm{ppm}\right): 2.00(\mathrm{bs}, 1 \mathrm{H}), 2.53$ (bs, $1 \mathrm{H}), 3.57-3.80(\mathrm{~m}, 4 \mathrm{H}), 3.92-4.00(\mathrm{~m}, 1 \mathrm{H}), 4.67(\mathrm{~s}, 2 \mathrm{H}), 7.50(\mathrm{~m}, 2 \mathrm{H}), 8.22(\mathrm{~m}$, $2 \mathrm{H}) ;{ }^{13} \mathrm{C}$ NMR $\left(100.6 \mathrm{MHz}, \mathrm{CDCl}_{3}, \delta, \mathrm{ppm}\right): 64.0,70.9,72.4,123.8,127.9,145.4$, 147.6. 1-(bis(4-methoxyphenyl)(phenyl)methoxy)-3-((4-nitrobenzyl)oxy)propan-2-ol 10. To a stirred solution of diol $9(790 \mathrm{mg}, 3.5 \mathrm{mmol}, 1.0$ eq.) in $20 \mathrm{~mL}$ THF (anh.):pyridine (anh.) =3:2 (v:v) 4,4'-dimethoxytrityl chloride (1180 mg, $3.5 \mathrm{mmol}, 1.0$ eq.) was added in three intervals of each $40 \mathrm{~min}$ at RT, under argon atmosphere and stirred overnight. The solvent was removed, $40 \mathrm{~mL} \mathrm{NaHCO}$ (sat., aq.) was added and it was extracted with EtOAc $(3 \times 50 \mathrm{~mL})$. The combined organic layer was washed with brine $(2 \times 30 \mathrm{~mL})$, dried over $\mathrm{Na}_{2} \mathrm{SO}_{4}$, filtered, and the solvent was removed. The yellow crude oil was purified by column chromatography $\left(\mathrm{SiO}_{2}\right.$ vs $20 \mathrm{v} \% \rightarrow 40 \mathrm{v} \%$ EtOAc in cyclohexane $+3 \mathrm{v} \%$ DIPEA) to obtain $1590 \mathrm{mg}(3.0 \mathrm{mmol}, 86 \%)$ of the product as yellowish foam. HRMS $\mathrm{m} / \mathrm{z}:[\mathrm{M}+$ $\mathrm{Na}]^{+}$calculated for $\mathrm{C}_{31} \mathrm{H}_{31} \mathrm{NO}_{7} \mathrm{Na}^{+}$552.1993; found, 552.1992; ${ }^{1} \mathrm{H}$ NMR $(400.1$ $\left.\mathrm{MHz}, \mathrm{CDCl}_{3}, \delta, \mathrm{ppm}\right): 2.37(\mathrm{~m}, 1 \mathrm{H}), 3.25(\mathrm{~m}, 2 \mathrm{H}), 3.58-3.66(\mathrm{~m}, 2 \mathrm{H}), 3.79(\mathrm{~s}, 6 \mathrm{H})$ $4.00(\mathrm{~m}, 1 \mathrm{H}), 4.62(\mathrm{~s}, 2 \mathrm{H}), 6.81(\mathrm{~m}, 4 \mathrm{H}), 7.16-7.24(\mathrm{~m}, 1 \mathrm{H}), 7.27-7.33(\mathrm{~m}, 6 \mathrm{H})$, 7.39-7.44 (m, 4H), $8.17(\mathrm{~m}, 1 \mathrm{H}) ;{ }^{13} \mathrm{C}$ NMR $\left(100.6 \mathrm{MHz}, \mathrm{CDCl}_{3}, \delta\right.$, ppm): 55.3 $64.4,70.1,72.1,72.2,86.3,113.3,123.7,127.0,127.8128 .0,128.2,130.2,136.0$ 144.8, 145.8, 147.5, 158.7. 1-(bis(4-methoxyphenyl)(phenyl)methoxy)-3-((4nitrobenzyl)oxy)propan-2-yl (2-cyanoethyl) diisopropylphosphoramidite M3 DIPEA ( $1850 \mathrm{mg}, 14.3 \mathrm{mmol}, 6.6$ eq.) and $100 \mathrm{mg}$ of molecular sieves $(3 \AA$ ) were added under argon atmosphere at $0{ }^{\circ} \mathrm{C}$ to a solution of DMT precursor 10 (1148 mg, $2.2 \mathrm{mmol}, 1.0$ eq.) in $10 \mathrm{~mL}$ of anhydrous DCM. Then, 2-cyanoethyl- $N$ $\mathrm{N}$-diisopropylchlorophosphoramidite $(600 \mathrm{mg}, 2.5 \mathrm{mmol}, 1.15 \mathrm{eq}$.) was added. The reaction mixture was stirred at $0{ }^{\circ} \mathrm{C}$ for $30 \mathrm{~min}$ and then allowed to reach $\mathrm{RT}$. The solvent was removed and the residue was purified by column chromatography 
$\left(\mathrm{SiO}_{2}\right.$ vs $33 \mathrm{v} \%$ EtOAc in cyclohexane $+3 \mathrm{v} \%$ DIPEA) to obtain $1521 \mathrm{mg}(2.1$ mmol, 96\%) of the product as a yellowish foam. HRMS $\mathrm{m} / z:[\mathrm{M}+\mathrm{H}]^{+}$calculated for $\mathrm{C}_{40} \mathrm{H}_{49} \mathrm{~N}_{3} \mathrm{O}_{8} \mathrm{P}^{+}$730.3252; found, 730.3253; ${ }^{1} \mathrm{H}$ NMR (400.1 MHz, $\mathrm{CDCl}_{3}, \delta$, ppm): $1.04-1.20(\mathrm{~m}, 12 \mathrm{H}), 2.42-2.61(\mathrm{~m}, 2 \mathrm{H}), 3.17-3.35(\mathrm{~m}, 2 \mathrm{H}), 3.50-3.65(\mathrm{~m}$, $2 \mathrm{H}), 3.66-3.89(\mathrm{~m}, 4 \mathrm{H}), 3.78(\mathrm{~s}, 6 \mathrm{H}), 4.18(\mathrm{~m}, 1 \mathrm{H}), 4.57-4.65(\mathrm{~m}, 2 \mathrm{H}), 6.76-6.84$ (m, 4H), 7.17-7.24 (m, 1H), 7.24-7.27 (m, 2H), 7.28-7.35 (m, 4H), 7.36-7.46 (m, $4 \mathrm{H}), 8.12-8.18(\mathrm{~m}, 2 \mathrm{H}) ;{ }^{13} \mathrm{C}$ NMR $\left(100.6 \mathrm{MHz}, \mathrm{CDCl}_{3}, \delta, \mathrm{ppm}\right): 20.4,24.8,43.3$, $55.3,58.4,63.9,71.8,72.1,72.6,86.1,113.2,117.8,123.6,126.9,127.6,127.9,128.3$, $130.2,136.2,145.0,146.2,147.4,158.6 ;{ }^{31} \mathrm{P} \mathrm{NMR}\left(161.9 \mathrm{MHz} \mathrm{CDCl}_{3}, \delta\right.$, ppm): 149.4 .

Synthesis of phosphoramidite monomer M4. Monomer M4 was synthesized in four steps as shown in Supplementary Fig. 56. Synthesis details are described as follows. Intermediates 11 and $\mathbf{1 2}$ were synthesized following reported procedures ${ }^{39}$. 1-(bis(4-methoxyphenyl)(phenyl)methoxy)-3-((triisopropylsilyl)oxy)propan-2ol 13. To a stirred solution of TIPS-protected glycerol $(3641 \mathrm{mg}, 14.7 \mathrm{mmol}, 1.0$ eq.) in $30 \mathrm{~mL}$ of 3:2 (v:v) mixture of THF (anh.):pyridine (anh.), was added at RT under argon atmosphere, 4,4'-dimethoxytrityl chloride ( $4968 \mathrm{mg}, 14.7 \mathrm{mmol}, 1.0$ eq.) in three intervals of each $40 \mathrm{~min}$. The mixture was then stirred overnight. The solvent was removed and $50 \mathrm{~mL} \mathrm{NaHCO}$ (sat., aq.) was added. The mixture was extracted with EtOAc $(3 \times 100 \mathrm{~mL})$, the combined organic layer was washed with brine $(2 \times 50 \mathrm{~mL})$, dried over $\mathrm{Na}_{2} \mathrm{SO}_{4}$, filtered, and the solvent was removed. The obtained yellow crude oil was purified by column chromatography $\left(\mathrm{SiO}_{2}\right.$ vs $40 \mathrm{v} \%$ EtOAc in cyclohexane $+2 \mathrm{v} \%$ DIPEA) to obtain $6279 \mathrm{mg}(11.4 \mathrm{mmol}, 78 \%)$ of 13 as a colorless oil. HRMS $m / z:[\mathrm{M}+\mathrm{Na}]^{+}$calculated for $\mathrm{C}_{33} \mathrm{H}_{46} \mathrm{O}_{5} \mathrm{SiNa}^{+}$573.3007; found $573.3013 ;{ }^{1} \mathrm{H} \mathrm{NMR}\left(400.1 \mathrm{MHz}, \mathrm{CDCl}_{3}, \delta, \mathrm{ppm}\right): 1.01-1.15(\mathrm{~m}, 21 \mathrm{H}), 2.50$ (m, 1H), 3.14-3.25 (m, 1H), $3.65(\mathrm{~m}, 2 \mathrm{H}), 3.76(\mathrm{~m}, 2 \mathrm{H}), 3.79(\mathrm{~s}, 6 \mathrm{H}), 6.82(\mathrm{~m}, 4 \mathrm{H})$, 7.16-7.18 $(\mathrm{m}, 1 \mathrm{H}), 7.27(\mathrm{~m}, 2 \mathrm{H}), 7.31(\mathrm{~m}, 4 \mathrm{H}), 7.42(\mathrm{~m}, 2 \mathrm{H}) ;{ }^{13} \mathrm{C}$ NMR $(100.6$ $\left.\mathrm{MHz}, \mathrm{CDCl}_{3}, \delta, \mathrm{ppm}\right): 11.8,17.9,55.2,64.2,64.5,71.2,86.1,113.1,126.6,127.7$ 128.1, 130.0, 136.1, 144.9, 158.4. 1-(bis(4-methoxyphenyl)(phenyl)methoxy)-3((triisopropylsilyl)oxy)propan-2-yl (2-cyanoethyl) diisopropylphosphoramidite M4. In total, $2050 \mathrm{mg}$ of $\mathbf{1 3}(3.7 \mathrm{mmol}, 1.0 \mathrm{eq}$.) were dissolved in $10 \mathrm{~mL}$ anhydrous DCM. Then, DIPEA ( $4 \mathrm{~mL}, 6.0$ eq.), molecular sieves ( $3 \AA$ ) and 2-cyanoethyl- $N, N$ diisopropylchlorophosphoramidite $(970 \mathrm{mg}, 4.08 \mathrm{mmol}, 1.10 \mathrm{eq}$.) were added under argon atmosphere at $0^{\circ} \mathrm{C}$. The reaction mixture was stirred at $0{ }^{\circ} \mathrm{C}$ for 30 min and then allowed to reach RT. DCM was removed and the residue was purified by column chromatography $\left(\mathrm{SiO}_{2}\right.$ vs $33 \mathrm{v} \%$ EtOAc in cyclohexane $+2 \mathrm{v} \%$ DIPEA) to obtain $\mathbf{M 4}$ as a colorless foam in 95\% yield. HRMS $m / z:[\mathrm{M}+\mathrm{H}]^{+}$calculated for $\mathrm{C}_{42} \mathrm{H}_{64} \mathrm{~N}_{2} \mathrm{O}_{3} \mathrm{PSi}^{+}$751.4266; found 751.4279; ${ }^{1} \mathrm{H}$ NMR (400.1 MHz, $\mathrm{CDCl}_{3}, \delta$, ppm): 0.96-1.02 (m, 21H), 1.04-1.20 (m, 12H), 2.47-2.60 (m, 2H), 3.58-3.68 (m, $2 \mathrm{H}), 3.69-3.89(\mathrm{~m}, 4 \mathrm{H}), 3.76(\mathrm{~m}, 2 \mathrm{H}), 3.78(\mathrm{~s}, 6 \mathrm{H}), 4.02(\mathrm{~m}, 1 \mathrm{H}), 6.78-6.82(\mathrm{~m}$, $4 \mathrm{H})$, 7.17-7.22 (m, 1H), 7.24-7.28 (m, 2H), 7.32-7.36 (m, 4H), 7.44-7.48 (m, $2 \mathrm{H})$; ${ }^{13} \mathrm{C}$ NMR $\left(100.6 \mathrm{MHz} \mathrm{CDCl}_{3}, \delta\right.$, ppm): 11.86, 17.10, 17.97, 20.67, 24.53, 24.60, $39.15,43.23,48.57,55.18,64.02,74.59,112.96,126.5,126.6,127.6,128.2,128.3$, 130.1; ${ }^{31} \mathrm{P}$ NMR (161.9 MHz, $\left.\mathrm{CDCl}_{3}, \delta, \mathrm{ppm}\right): 149.3$.

Oligomer synthesis. Oligo(phosphodiester)s H1-H3 and P1-P13 were synthesized by solid-phase automated phosphoramidite chemistry on an Expedite oligonucleotide synthesizer (Perseptive Biosystem 8900), as previously reported ${ }^{29}$. H1-H2 and P1-P5 were synthesized using M1 (0-bit) and M2 (1-bit) as a binary alphabet (Supplementary Table 1). H3 and P6-P11 were synthesized using M1 and M3 as an invisible binary ink (Supplementary Table 2). P12 and P13 were synthesized using M1, M3, and M4 as molecular alphabet (Supplementary Table 3). All the phosphoramidite monomers were dissolved in anhydrous acetonitrile (100 mM solution) under argon, placed in the synthesizer with all the reagents and primed twice. The solid support-filled column $(1 \mu \mathrm{mol}$ scale $)$ was placed in the synthesizer and the automated syntheses of the different sequences were started with DMT-ON mode, using the standard protocol except for the sequences containing the monomer M4, for which the coupling of the corresponding phosphoramidite was repeated twice. The DMT-protected polymers were cleaved from the solid support using a 1:1 (v:v) solution of $28 \mathrm{w} \%$ ammonia and $40 \mathrm{w} \%$ methylamine: two syringes, one of which contains $0.5 \mathrm{~mL}$, were placed at the two ends of the columns, pushed from one side, and pulled from the other for $1 \mathrm{~h}$. The cleaved polymers were collected in a microtube, the columns were afterwards washed with $0.5 \mathrm{~mL}$ of ammonia/methylamine solution, then collected in the same microtube, to which a volume of $1 \mathrm{~mL}$ of $100 \mathrm{mg} / \mathrm{mL}$ sodium chloride solution was added. The DMT-protected polymers were then purified on PolyPak II reversephase cartridges, which had been previously flushed with $0.5 \mathrm{~mL} \mathrm{MeCN}$ and then with $1 \mathrm{~mL}$ of $2 \mathrm{M}$ triethylammonium acetate (TEAA) buffer. For all polymers except P12 and P13, the polymer/salt mixtures were loaded on the cartridges and the failure sequences were washed with twice $0.5 \mathrm{~mL}$ of a salt wash solution $(5 \%$ $\mathrm{MeCN} / 100 \mathrm{mg} \mathrm{NaCl} / 1 \mathrm{~mL}$ water). The cartridges were then washed with twice 1 $\mathrm{mL}$ of aqueous $2 \%$ TFA to remove the last protecting DMT group and twice $1 \mathrm{~mL}$ of deionized water. The polymers were washed out with $1 \mathrm{~mL}$ of $50 \% \mathrm{MeCN}$ in water containing $0.5 \%$ ammonium hydroxide, then collected in a microtube and lyophilized. In all cases, the sequences were obtained as triethylammonium salts. The formed oligomers were characterized by ${ }^{1} \mathrm{H}$ NMR, ${ }^{31} \mathrm{P}$ NMR, HPLC, ESIHRMS and MS/MS. Yields: 99.2\% (H1), 78.3\% (H2), 99.2\% (H3), 89.3\% (P1), 96.0\% (P2), 87.9\% (P3), 96.0\% (P4), 99.2\% (P5), 90.0\% (P6), 85.7\% (P7), 82.3\% (P8), 93.0\% (P9), 91.5\% (P10), 82.3\% (P11), 97.6\% (P12), 53.0\% (P13). Purity from HPLC: 88\% (H1), 92\% (H2), 90\% (H3), 91\% (P1), 90\% (P2), 92\% (P3), 95\% (P4), 93\% (P5), 92\% (P6), 91\% (P7), 87\% (P8), 92\% (P9), 92\% (P10), 92\% (P11), $81 \%$ (P12), and $85 \%$ (P13).

TIPS deprotection for polymers containing M4. The DMT-protected copolymer P12 was dissolved in $115 \mu \mathrm{L}$ DMSO, then $60 \mu \mathrm{L}$ of $\mathrm{Et}_{3} \mathrm{~N}$ was added and the solution was mixed gently. Afterwards, $75 \mu \mathrm{L}$ of $\mathrm{Et}_{3} \mathrm{~N}$.3HF was added and the mixture was heated at $65^{\circ} \mathrm{C}$ for $2.5 \mathrm{~h}$. The deprotected polymer solution was cooled, and then $1.75 \mathrm{~mL}$ of aq. sat. $\mathrm{NH}_{4} \mathrm{Cl}$ solution was added. The mixture was loaded on PolyPak cartridge previously treated with $0.5 \mathrm{~mL} \mathrm{MeCN}$ and $1 \mathrm{~mL}$ of $2 \mathrm{M}$ TEAA buffer and purified as described above in the section 'Oligomer synthesis'.

Photomodification. Polymers H1-H3 and P1-P13 were photo-irradiated, thus resulting in polymers $\mathbf{H} \mathbf{1}^{\prime}-\mathbf{H} \mathbf{3}^{\prime}$ and $\mathbf{P} \mathbf{1}^{\prime}-\mathbf{P} \mathbf{1 3}^{\prime}$ (Supplementary Tables $\mathbf{1 - 3}$ ). The general procedure is as follows: the oligo(phosphodiester) was dissolved in methanol-d4 $(1.0 \mathrm{mM})$ under argon atmosphere. Then, $100 \mu \mathrm{L}$ of the formed solution were filled into a small glass vial under exclusion of air and this vial was placed on the glass surface of a UV lamp (Vilber Lourmat; $\lambda=365 \mathrm{~nm}$ ). The solution was irradiated for $60 \mathrm{~min}$ in a closed box and the solvent was afterwards removed to recover the modified sequences. The modified oligomers were characterized by ${ }^{1} \mathrm{H}$ NMR, ${ }^{31} \mathrm{P}$ NMR, ESI-HRMS and MS/MS.

Nuclear magnetic resonance spectroscopy. All NMR spectra were recorded on a Bruker Avance 400 spectrometer equipped with an Ultrashield magnet. Chemical shifts $(\delta)$ are reported in parts per million (ppm) against solvent residual signal $\left({ }^{1} \mathrm{H}\right.$ $\mathrm{NMR}, \mathrm{CDCl}_{3}: \delta=7.26 \mathrm{ppm} ;{ }^{13} \mathrm{C} \mathrm{NMR}, \mathrm{CDCl}_{3}: \delta=77.16 \mathrm{ppm} ;{ }^{1} \mathrm{H}$ NMR, $\mathrm{CD}_{3} \mathrm{OD}$ $\delta=3.31 \mathrm{ppm} ;{ }^{13} \mathrm{C}$ NMR, $\mathrm{CD}_{3} \mathrm{OD}: \delta=49.00 \mathrm{ppm}$.) ${ }^{1} \mathrm{H}$ NMR spectra were recorded at $400.13 \mathrm{MHz},{ }^{13} \mathrm{C}$ NMR spectra at $100.62 \mathrm{MHz}$. The NMR solvents deuterated chloroform (99.8\%, chloroform-d1) and deuterated methanol (99.8\%, methanold4) were purchased from Aldrich.

High-performance liquid chromatography. Ion exchange HPLC (IE-HPLC) analyses were performed using Agilent 1220 Infinity LC system with manual injector and single wavelength UV detector. The system was equipped with ion-exchange column (DIONEX, DNA Pac PA 100, $4 \times 250 \mathrm{~mm}$ ). The chromatograms were recorded at $\lambda=260 \mathrm{~nm}$. Experimental conditions: phase A: $10 \% \mathrm{MeCN} 20 \% 2 \mathrm{M} \mathrm{NH}_{3}$ in water, phase B: $2.5 \mathrm{M} \mathrm{NaCl}$ in water; gradient elution: $0-3 \mathrm{~min} 5 \% \mathrm{~B}, 3-23 \mathrm{~min}$ from $5 \% \mathrm{~B}$ to $30 \%$ B, $23-28 \min 30 \%$ B, $28-35 \mathrm{~min}$ from 30 to $5 \%$ B; flow rate: $1 \mathrm{~mL} / \mathrm{min}$. For IEHPLC analysis MilliQ water, $\mathrm{NaCl}$ (BioXtra, $\geq 99.5 \%$, Sigma-Aldrich) and acetonitrile (ACN, HPLC grade, $\geq 99.93 \%$, Sigma-Aldrich) were used. Oligomer purity was calculated based on signal area integrals using formula:

$$
\text { Purity }[\%]=\frac{I_{\mathrm{P}} \times 100}{\sum I_{n}}
$$

where $I_{\mathrm{P}}$ is the surface area of the signal representing product and $\sum I_{n}$ is a sum of signals areas of other signals present in the HPLC chromatogram occurring in range 5-35 min of elution time. The integrations were calculated in OpenLab software using automatic integration mode.

Electrospray ionization mass spectrometry. High-resolution MS and MS/MS experiments were performed using a QStar Elite mass spectrometer (Applied Biosystems SCIEX, Concord, ON, Canada) equipped with an electrospray ionization (ESI) source operated in the negative mode. The capillary voltage was set at $-4200 \mathrm{~V}$ and the cone voltage at $-75 \mathrm{~V}$. In this hybrid instrument, ions were measured using an orthogonal acceleration time-of-flight (oa-TOF) mass analyzer. In the MS/MS mode, a quadrupole was used for selection of precursor ions to be further submitted to collision-induced dissociation (CID) in a collision cell. Accurate mass measurements were performed using internal calibration. In this instrument, air was used as the nebulizing gas (10 psi) while nitrogen was used as the curtain gas ( $20 \mathrm{psi})$ as well as the collision gas. Instrument control, data acquisition, and data processing of all experiments were achieved using Analyst software (QS 2.0) provided by Applied Biosystems. Polymer solutions were prepared in methanol supplemented with ammonium acetate $(3 \mathrm{mM})$ and introduced in the ionization source using a syringe pump (flow rate: $10 \mu \mathrm{L} / \mathrm{min}$ ). Dissociation reactions proceed via cleavages of backbone bonds of the poly(phosphodiester) chains that give rise to $a$-containing (i.e., $\mathrm{a}_{\mathrm{i}}^{\mathrm{z}-}, \mathrm{b}_{\mathrm{i}}^{\mathrm{z}-}, \mathrm{c}_{\mathrm{i}}^{\mathrm{z}-}, \mathrm{d}_{\mathrm{i}}^{\mathrm{z}-}$ ) or $\omega$-containing (i.e. $\mathrm{w}_{\mathrm{i}}^{\mathrm{Z}-}, \mathrm{x}_{\mathrm{i}}^{\mathrm{z-}}, \mathrm{y}_{\mathrm{i}}^{\mathrm{z-}}, \mathrm{z}_{\mathrm{i}}^{\mathrm{Z}-}$ ) fragments typically employed to reconstruct the sequence from the left- or from the right-hand side of the chain, respectively.

\section{Data availability}

All data generated and analyzed during this study are included in this article and its Supplementary Information, and are also available from the authors upon reasonable request.

Received: 19 June 2019 Accepted: 22 July 2019

Published online: 04 September 2019 


\section{References}

1. Colquhoun, H. \& Lutz, J.-F. Information-containing macromolecules. Nat. Chem. 6, 455-456 (2014).

2. Lutz, J.-F. Coding macromolecules: inputting information in polymers using monomer-based alphabets. Macromolecules 48, 4759-4767 (2015).

3. Rutten, M. G. T. A., Vaandrager, F. W., Elemans, J. A. A. W. \& Nolte, R. J. M. Encoding information into polymers. Nat. Rev. Chem. 2, 365-381 (2018).

4. Zhirnov, V., Zadegan, R. M., Sandhu, G. S., Church, G. M. \& Hughes, W. L. Nucleic acid memory. Nat. Mater. 15, 366-370 (2016).

5. Trinh, T. T., Oswald, L., Chan-Seng, D. \& Lutz, J.-F. Synthesis of molecularly encoded oligomers using a chemoselective "AB + CD" iterative approach. Macromol. Rapid Commun. 35, 141-145 (2014).

6. Roy, R. K. et al. Design and synthesis of digitally-encoded polymers that can be decoded and erased. Nat. Commun. 6, 7237 (2015).

7. Zydziak, N. et al. Coding and decoding libraries of sequence-defined functional copolymers synthesized via photoligation. Nat. Commun. 7, 13672 (2016).

8. Boukis, A. C., Reiter, K., Frölich, M., Hofheinz, D. \& Meier, M. A. R. Multicomponent reactions provide key molecules for secret communication. Nat. Commun. 9, 1439 (2018).

9. Boukis, A. C. \& Meier, M. A. R. Data storage in sequence-defined macromolecules via multicomponent reactions. Eur. Polym. J. 104, 32-38 (2018).

10. Martens, S. et al. Multifunctional sequence-defined macromolecules for chemical data storage. Nat. Commun. 9, 4451 (2018)

11. Huang, Z. et al. Binary tree-inspired digital dendrimer. Nat. Commun. 10, 1918 (2019).

12. Bonnet, J., Subsoontorn, P. \& Endy, D. Rewritable digital data storage in live cells via engineered control of recombination directionality. Proc. Natl. Acad. Sci. USA 109, 8884 (2012).

13. Mayer, C., McInroy, G. R., Murat, P., Van Delft, P. \& Balasubramanian, S. An epigenetics-inspired DNA-based data storage system. Angew. Chem. Int. Ed. 55, 11144-11148 (2016).

14. Lehn, J.-M. From supramolecular chemistry towards constitutional dynamic chemistry and adaptive chemistry. Chem. Soc. Rev. 36, 151-160 (2007).

15. Stuart, M. A. C. et al. Emerging applications of stimuli-responsive polymer materials. Nat. Mater. 9, 101 (2010).

16. Wojtecki, R. J., Meador, M. A. \& Rowan, S. J. Using the dynamic bond to access macroscopically responsive structurally dynamic polymers. Nat. Mater. 10, 14-27 (2011).

17. Chen, M., Zhong, M. \& Johnson, J. A. Light-controlled radical polymerization: mechanisms, methods, and applications. Chem. Rev. 116, 10167-10211 (2016).

18. Dadashi-Silab, S., Doran, S. \& Yagci, Y. Photoinduced electron transfer reactions for macromolecular syntheses. Chem. Rev. 116, 10212-10275 (2016).

19. Khan, A., Kaiser, C. \& Hecht, S. Prototype of a photoswitchable foldamer. Angew. Chem. Int. Ed. 45, 1878-1881 (2006).

20. Mes, T., van der Weegen, R., Palmans, A. R. A. \& Meijer, E. W. Single-chain polymeric nanoparticles by stepwise folding. Angew. Chem. Int. Ed. 50, 5085-5089 (2011).

21. Zhao, Y. \& He, J. Azobenzene-containing block copolymers: the interplay of light and morphology enables new functions. Soft Matter 5, 2686-2693 (2009).

22. Schumers, J.-M., Fustin, C.-A. \& Gohy, J.-F. Light-responsive block copolymers. Macromol. Rapid Commun. 31, 1588-1607 (2010).

23. Lendlein, A., Jiang, H., Jünger, O. \& Langer, R. Light-induced shape-memory polymers. Nature 434, 879 (2005).

24. Scott, T. F., Schneider, A. D., Cook, W. D. \& Bowman, C. N. Photoinduced plasticity in cross-linked polymers. Science 308, 1615 (2005).

25. Burnworth, M. et al. Optically healable supramolecular polymers. Nature $\mathbf{4 7 2}$ 334 (2011).

26. Al Ouahabi, A., Charles, L. \& Lutz, J.-F. Synthesis of non-natural sequenceencoded polymers using phosphoramidite chemistry. J. Am. Chem. Soc. 137, 5629-5635 (2015).

27. Caruthers, M. H. Gene synthesis machines: DNA chemistry and its uses. Science 230, 281-285 (1985).

28. Lutz, J.-F., Ouchi, M., Liu, D. R. \& Sawamoto, M. Sequence-controlled polymers. Science 341, 1238149 (2013).

29. Al Ouahabi, A., Kotera, M., Charles, L. \& Lutz, J.-F. Synthesis of monodisperse sequence-coded polymers with chain lengths above DP100. ACS Macro Lett. 4, 1077-1080 (2015).

30. König, N. F., Al Ouahabi, A., Poyer, S., Charles, L. \& Lutz, J.-F. A simple postpolymerization modification method for controlling side-chain information in digital polymers. Angew. Chem. Int. Ed. 56, 7297-7301 (2017).
31. Al Ouahabi, A., Amalian, J.-A., Charles, L. \& Lutz, J.-F. Mass spectrometry sequencing of long digital polymers facilitated by programmed inter-byte fragmentation. Nat. Commun. 8, 967 (2017)

32. Klán, P. et al. Photoremovable protecting groups in chemistry and biology: reaction mechanisms and efficacy. Chem. Rev. 113, 119-191 (2013).

33. Durbeej, B. \& Eriksson, L. A. Reaction mechanism of thymine dimer formation in DNA induced by UV light. J. Photochem. Photobiol. A 152, 95-101 (2002).

34. Lönnberg, H. Cleavage of RNA phosphodiester bonds by small molecular entities: a mechanistic insight. Org. Biomol. Chem. 9, 1687-1703 (2011).

35. Cafferty, B. J. et al. Storage of information using small organic molecules. ACS Cent. Sci. 5, 911-916 (2019).

36. Arppe, R. \& Sørensen, T. J. Physical unclonable functions generated through chemical methods for anti-counterfeiting. Nat. Rev. Chem. 1, 0031 (2017).

37. Xu, Y., Hong, Y. J., Tantillo, D. J. \& Brown, M. K. Intramolecular chirality transfer $[2+2]$ cycloadditions of allenoates and alkenes. Org. Lett. 19, 3703-3706 (2017)

38. Šolomek, T., Mercier, S., Bally, T. \& Bochet, C. G. Photolysis of orthonitrobenzylic derivatives: the importance of the leaving group. Photochem. Photobiol. Sci. 11, 548-555 (2012).

39. Haraldsson, G. G., Stefansson, T. \& Snorrason, H. Magnesium bromide as a mild and efficient selective deblocking agent for isopropylidene and trityl protecting groups. Acta Chem. Scand. 52, 824-826 (1998).

\section{Acknowledgements}

J.-F.L. thanks the H2020 program of the European Union (project Euro-Sequences, H2020-MSCA-ITN-2014, grant agreement no. 642083) and the CNRS for financial support. The Ph.D. position of N.F.K. is supported by the ITN Euro-Sequences. L.C. acknowledges support from Spectropole, the Analytical Facility of Aix-Marseille University, by allowing a special access to the instruments purchased with European Funding (FEDER OBJ2142-3341)

\section{Author contributions}

J.-F.L. designed the study, supervised research, and wrote the paper. N.F.K., A.A.O., and J.-F.L. conceptualized monomer and polymer design. N.F.K., L.O., and A.A.O. synthesized the monomers. N.F.K. and A.A.O. synthesized the polymers and performed photomodification experiments. R.S. performed HPLC measurements. L.C. performed ESIHRMS and MS/MS sequencing measurements and interpreted all MS data. All the authors analyzed the data, provided figures, and commented on the manuscript.

\section{Additional information}

Supplementary Information accompanies this paper at https://doi.org/10.1038/s41467019-11566-2.

\section{Competing interests: The authors declare no competing interests.}

Reprints and permission information is available online at http://npg.nature.com/ reprintsandpermissions/

Peer review information: Nature Communications thanks the anonymous reviewers for their contribution to the peer review of this work.

Publisher's note: Springer Nature remains neutral with regard to jurisdictional claims in published maps and institutional affiliations.

Open Access This article is licensed under a Creative Commons Attribution 4.0 International License, which permits use, sharing, adaptation, distribution and reproduction in any medium or format, as long as you give appropriate credit to the original author(s) and the source, provide a link to the Creative Commons license, and indicate if changes were made. The images or other third party material in this article are included in the article's Creative Commons license, unless indicated otherwise in a credit line to the material. If material is not included in the article's Creative Commons license and your intended use is not permitted by statutory regulation or exceeds the permitted use, you will need to obtain permission directly from the copyright holder. To view a copy of this license, visit http://creativecommons.org/ licenses/by/4.0/.

(C) The Author(s) 2019 